\title{
Application of an Integrated Omics Approach for Identifying Host Proteins That Interact With Odontoglossum ringspot virus Capsid Protein
}

\author{
Pin-Chun Lin, ${ }^{1,2}$ Wen-Chi Hu, ${ }^{1}$ Shu-Chuan Lee, ${ }^{1}$ Ying-Lan Chen, ${ }^{4,5}$ Chi-Ying Lee, ${ }^{4}$ Yet-Ran Chen, ${ }^{4}$ \\ Li-Yu Daisy Liu, ${ }^{6}$ Po-Yen Chen, ${ }^{1}$ Shih-Shun Lin, ${ }^{2,3,4}$ and Ya-Chun Chang ${ }^{1}$ \\ ${ }^{1}$ Department of Plant Pathology and Microbiology, National Taiwan University, 1, Sec. 4, Roosevelt Rd., Taipei, Taiwan; \\ ${ }^{2}$ Institute of Biotechnology, National Taiwan University, 81, Chang-Xing St., Taipei, Taiwan; ${ }^{3}$ Genome and Systems Biology \\ Degree Program, National Taiwan University, 1, Sec. 4, Roosevelt Rd., Taipei, Taiwan; ${ }^{4}$ Agricultural Biotechnology Research \\ Center, Academia Sinica, 128, Academia Rd, Sec. 2, Taipei, Taiwan; ${ }^{5}$ Institute of Plant Biology and Department of Life Science, \\ National Taiwan University, 1, Sec. 4, Roosevelt Rd., Taipei, Taiwan; ${ }^{6}$ Department of Agronomy, National Taiwan University, 1 , \\ Sec. 4, Roosevelt Rd., Taipei, Taiwan
}

Submitted 26 August 2014. Accepted 19 January 2015.

The glutamic acid at position $100\left(\mathrm{E}^{100}\right)$ in the capsid protein (CP) of Odontoglossum ringspot virus (ORSV) plays an important role in long-distance viral movement in Nicotiana benthamiana. The ORSV ${ }^{\mathrm{E} 100 \mathrm{~A}}$ mutant, which has a glutamic acid to alanine substitution, shows a loss of systemic infectivity in $N$. benthamiana. Transmission electron microscopy and size-exclusion chromatography assays showed that $E^{100}$ is essential for CP-CP interaction and viral particle assembly. To identify the ORSV triggering or response genes and CP-interacting proteins (CP-IP), an integrated omics approach based on nextgeneration sequencing and proteomics profiling was used in this study. The whole-transcriptomes of healthy and ORSV-infected leaves of $N$. benthamiana were analyzed, and the gene information was used to create a $N$. benthamiana protein database that was used for protein identification following mass spectrometry analysis. The integrated omics approach identified several putative host proteins that interact with ORSV $C P^{W T}$ and were categorized as photosystem subunits, defenseassociated proteins, and cell division components. The expression pattern and CP interaction of these CP-IP were examined by semiquantitative reverse transcription polymerase chain reaction and an in vitro binding assay, respectively, to verify the in silico data. Among these proteins, a proteinase inhibitor of $N$. benthamiana (NbPI2) was highly associated with $\mathrm{CP}^{\mathrm{E} 100 \mathrm{~A}}$ as compared with $C P^{\mathrm{WT}}$, and $N b P I 1$ and $\mathrm{NbPI2}$ were highly induced in ORSV-infected plants. NbPI1- and NbPI2-silenced plants (via a Tobacco rattle virus-induced gene-silencing system) did not exhibit a difference in ORSV infection. Thus,

The raw transcriptome reads reported in this paper are available in the NCBI Short Read Archive under accession numbers SRR1552497 (healthy $N$. benthamiana) and SRR1552498 (ORSV-infected N. benthamiana). The transcriptome contig sequences of $N$. benthamiana are available in the ContigViews database.

Corresponding authors: S.-S. Lin; Telephone: +886-2-3366-6023; Fax: +886-2-3366-6001; E-mail: linss01@ntu.edu.tw; and Y.-C. Chang; Telephone: +886-2-3366-5209; Fax: +886-2-2362-0271; E-mail: ycchang@ntu. edu.tw

*The $\boldsymbol{e}$-Xtra logo stands for "electronic extra" and indicates that two supplementary figures and four supplementary tables are published online.

๑) 2015 The American Phytopathological Society whether NbPI1 and NbPI2 play a role in plant immunity requires further investigation. In summary, the integrated omics approach provides massive and valuable information to identify the ORSV CP-IP and these CP-IP will help us to understand the movement of this virus and plant-virus interaction.

Odontoglossum ringspot virus (ORSV) belongs to the genus Tobamovirus, which was originally isolated from the orchid Odontoglossum grande and threatens the orchid industry worldwide (Adams et al. 2009; Hong et al. 2011; Khentry et al. 2006; Rabindran et al. 2005; Wong et al. 1994). ORSV has been reported that can infect Chenopodiaceae and Solanaceae families in nature, including Nicotiana benthamiana, with systemic infection (Hilf and Dawson 1993). The laboratory-created mutant ORSV $^{\text {E100G }}$ has a Glu100Gly mutation on the ORSV capsid protein $(\mathrm{CP})$ that was generated by fragment swapping, and this mutant virus lost its systemic movement ability in N. benthamiana, resulting in nonsystemic infection (Lee 2008). Many reports have indicated that Tobacco mosaic virus (TMV) mutants with a $C P$ gene deletion also exhibited systemic movement deficiencies (Dawson et al. 1988; Holt and Beachy 1991; Takamatsu et al. 1987). Yu and Wong (1998) reported that the systemic spread of CP-deleted ORSV was greatly reduced. These findings suggested that the $\mathrm{CP}$ of tobamoviruses play an important role in systemic infection.

A tobacco protein, Tomato mosaic virus (ToMV) CP-IP-L (interacting protein-L), has been shown to assist in viral systemic movement (Li et al. 2005; Zhang et al. 2008). Pectin methylesterase (PME) interacts with the TMV movement protein (MP), which is responsible for virus cell-to-cell movement (Chen et al. 2000). The virus loses its systemic infection ability when the $M P$ gene was mutated or wild-type TMV was infected on the PME knock-down tobacco plants (Chen and Citovsky 2003; Chen et al. 2000). Furthermore, a transgenic tobacco plant expressing the cadmium ion-induced glycine-rich protein $(c d i G R P)$ gene, which is a low cadmium-inducing cell-wall component, was shown to block Turnip vein-clearing virus systemic movement (Ueki and Citovsky 2002). These results indicate that host components are involved in viral systemic movement. However, the limited number of identified CP-IP does not allow the mechanism of systemic movement to be studied. Identification of additional CP-IP candidates is required for 
characterizing the host-pathogen interaction network via a highthroughput systems biology approach.

The development of next-generation sequencing (NGS) has enabled whole-transcriptomic analyses of nonmodel organisms (Liu et al. 2014; Su et al. 2011; Van Moerkercke et al. 2013). Approximately 20,000 to 40,000 genes can be identified through NGS analysis and high-throughput reads of these transcriptomes can be converted to fragments per kilobase of transcript per million mapped reads (FPKM) or DESeq to represent differential expression (Howe et al. 2011). In plant pathology, the NGS technique has been applied to study phytoplasma-mediated leafy flower symptom development in Catharanthus roseus (Liu et al. 2014). The relational network among different genes was used to formulate a hypothesis to explain the mechanism of leafy flower symptoms (Liu et al. 2014), indicating the power of NGS in the study of plant-pathogen interactions. Whole-transcriptome sequencing is independent of genome sequence and provides precise amino acid sequences for mass spectrum predictions in proteomics studies.

Guarnieri et al. (2011) demonstrated that the de novo transcriptome of microalgae can be used for proteomic analyses, and several genes that are involved in the fatty acid and triacylglycerol biosynthetic machinery were identified. Furthermore, Van Moerkercke et al. (2013) combined transcriptome profiles and metabolic networks from omics data to reconstruct a metabolic pathway and discover missing enzymes for engineering metabolic study. Therefore, we define the "integrated omics approach" as a novel discovering strategy combining multiple high-throughput profiles to find new research directions.

To study the molecular mechanisms underlying the $N$. benthamiana-ORSV interactions and viral systemic movement, we created a new ORSV CP mutant virus, ORSV ${ }^{\mathrm{E} 100 \mathrm{~A}}$ that contains a restriction fragment length polymorphism (RFLP) marker. Observations with transmission electron microscopy, size-exclusion chromatography, and an in vitro CP-CP interaction assay showed that $\mathrm{CP}^{\mathrm{E} 100 \mathrm{~A}}$ leads to defective viral particle assembly. In addition, an integrated omics approach that combined proteomics and transcriptomics assays were used to identify the specific $\mathrm{CP}^{\mathrm{WT}}$-IP from healthy and ORSV-infected $N$. benthamiana plants. Furthermore, several experimental approaches, including semiquantitative reverse transcription polymerase chain reaction (RT-PCR), an in vitro binding assay, and virus-induced gene silencing (VIGS), were used to verify the differential expression, physical interaction, and gene function of these $\mathrm{CP}^{\mathrm{WT}}$-IP. Furthermore, one of the identified CP-IP, $N b P I 2$, was shown to be upregulated in ORSV-infected plants and strongly interacted with $\mathrm{CP}^{\mathrm{E} 100 \mathrm{~A}}$. The possible function of NbPI2 in ORSV infection was proposed in this study.

\section{RESULTS}

The conserved glutamic acid at position $100\left(E^{100}\right)$ residue in the CP of tobamoviruses.

Our previous results showed that $\mathrm{E}^{100}$ of the ORSV CP plays an important role in viral systemic movement in $N$. benthamiana (Lee 2008). The alignment of the CP sequences of tobamoviruses indicated that 10 out of 13 species have an $\mathrm{E}^{100}$ residue, Tobacco mild green mosaic virus and Obuda pepper virus have an aspartic acid residue $\left(\mathrm{D}^{100}\right)$, and only Cucumber green mottle mosaic virus has a valine residue $\left(\mathrm{V}^{100}\right)$ (Fig. 1A). Because glutamic acid and aspartic acid are acidic amino acids with carboxylate groups as side chains and similar biochemical properties, this conserved $\mathrm{E}^{100}$ in the $\mathrm{CP}$ may play an important role in virus infection. Based on the predicted three-dimensional structure of the $\mathrm{CP}$ protein, $\mathrm{E}^{100}$ is located on the loop region, which is oriented on the inner surface of the CP subunit that may respond to viral particle assembly (Fig. 1B). To examine the importance of $\mathrm{E}^{100}$, site-directed mutagenesis was performed on the pORSV ${ }^{\mathrm{WT}}$ infectious clone (Lee 2008) to substitute the $\mathrm{E}^{100}$ residue of $\mathrm{CP}$ with an alanine residue to generate pORSV ${ }^{\mathrm{E} 100 \mathrm{~A}}$ (Fig. 1C). A restriction enzyme site, $M s c \mathrm{I}$, was incorporated at the mutation site to distinguish ORSV ${ }^{\mathrm{E} 100 \mathrm{~A}}$ from ORSV ${ }^{\mathrm{WT}}$, using PCR-RFLP.
A

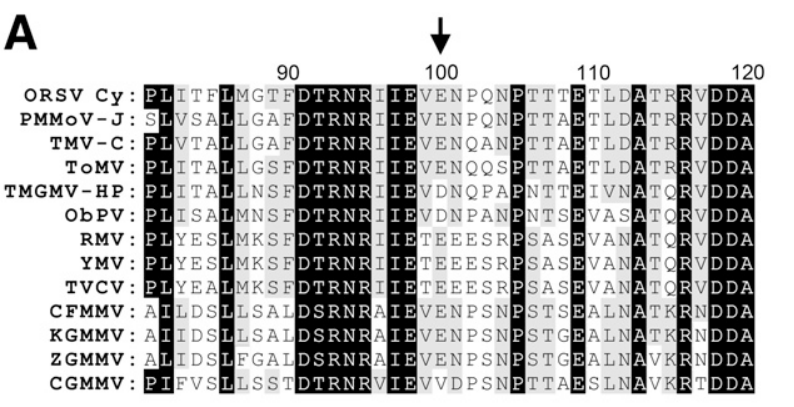

\section{B}

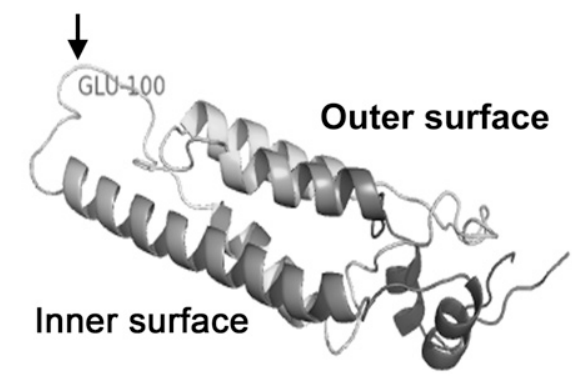

C
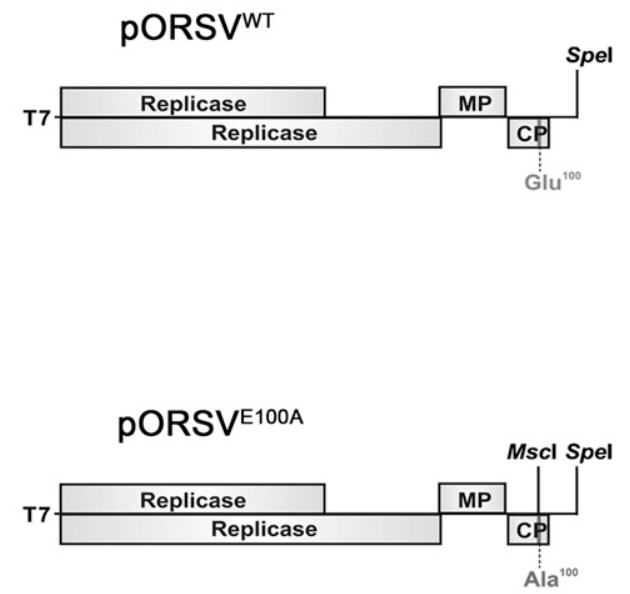

Fig. 1. The conserved amino acid $\left(\mathrm{E}^{100}\right)$ in the capsid protein $(\mathrm{CP})$ of Odontoglossum ringspot virus (ORSV). A, Amino acid sequence alignment of ORSV CP with other tobamoviruses. The arrow indicates the conserved glutamic acid (E) residue at the 100th position. B, Predicted three-dimensional structure of ORSV $\mathrm{CP}$. Four alpha helix structures and two loops are shown. The indicated $\mathrm{E}^{100}$ residue is located on the loop of the inner surface of the virus particle. $\mathrm{C}$, Schematic representations of the genomes of the $\mathrm{T} 7$ promoter-driven wild-type (ORSV ${ }^{\mathrm{WT}}$ ) and mutant (ORSV ${ }^{\mathrm{E} 100 \mathrm{~A}}$ ) $\mathrm{ORSV}_{\text {full-length }} \mathrm{cDNA}$ clones pORSV ${ }^{\mathrm{WT}}$ and $\mathrm{pORSV}^{\mathrm{E} 100 \mathrm{~A}}$, respectively. The 126-kDa replicase, 183-kDa replicase of the read-through form, 31-kDa movement protein (MP), and 18-kDa CP are shown. The only variability between the two clones is the change from $\mathrm{E}^{100}$ to $\mathrm{A}^{100}$ on the $\mathrm{CP}$. The MscI restriction enzyme site was created by polymerase chainn reaction-based mutagenesis, and the SpeI restriction enzyme site was used to linearize the DNA template for in vitro transcription. 
The infectivity assay of ORSV in $N$. benthamiana and Chenopodium quinoa.

The in vitro transcripts of pORSV ${ }^{\mathrm{WT}}$ and $\mathrm{pORSV}^{\mathrm{E} 100 \mathrm{~A}}$ were transfected into protoplasts of $N$. benthamiana. The results of the Northern blot analysis showed that ORSV ${ }^{\mathrm{WT}}$ and ORSV ${ }^{\mathrm{E} 100 \mathrm{~A}}$ replicated equally in single cells (Supplementary Fig. 1). However, ORSV ${ }^{\mathrm{E} 100 \mathrm{~A}}$ did not cause any symptoms on the systemic leaves of $N$. benthamiana, while inoculation with $\mathrm{ORSV}^{\mathrm{WT}}$ caused leaf curl symptoms in systemic leaves at 10 days postinoculation (dpi) (Fig. 2A). The RFLP results showed that the MscI-treated RT-PCR products of ORSV ${ }^{\mathrm{E} 100 \mathrm{~A}}$ were digested into 300- and 185-bp fragments, whereas those from the ORSV ${ }^{\mathrm{WT}}$ fragments remained uncut ( 485 bp) (Fig. 2B). The results of the Western blot analysis also confirmed that $\mathrm{ORSV}^{\mathrm{E} 100 \mathrm{~A}}$ was only detected in inoculated leaves but not in systemic leaves at $10 \mathrm{dpi}$, whereas ORSV ${ }^{\mathrm{WT}}$ could be detected in both types of leaves (Fig. 2C). Even at $30 \mathrm{dpi}^{\text {, ORSV }}{ }^{\mathrm{E} 100 \mathrm{~A}}$ still was not detected in the systemic leaves (data not shown). The difference in the protein mobility between $\mathrm{CP}^{\mathrm{WT}}$ and $\mathrm{CP}^{\mathrm{E} 100 \mathrm{~A}}$ was detected using Western blot analysis (Fig. 2C). C. quinoa was used to examine the cell-to-cell movements of both viruses. No differences in lesion formation, including number and size, were observed between the two viruses (Fig. 3A). These results demonstrated that the $\mathrm{E}^{100} \mathrm{~A}$ mutation in the $\mathrm{CP}$ greatly affected the systemic movement of ORSV in $N$. benthamiana. In addition, two molecular markers, including RFLP and CP protein mobility, provided convenient means for tracing $\mathrm{ORSV}^{\mathrm{WT}}$ and $\mathrm{ORSV}^{\mathrm{E} 100 \mathrm{~A}}$.

\section{$C P^{E 100 A}$ altered the CP-CP interaction and viral particle assembly.}

We first examined whether the $\mathrm{E}^{100} \mathrm{~A}$ mutation affects viral particle assembly through morphological observations, using immunosorbent electron microscopy (ISEM) (Fig. 3A). The ISEM data showed that ORSV ${ }^{\mathrm{WT}}$ viral particles were approximately $300 \mathrm{~nm}$ in length (Fig. 3A and B). The particle lengths of $\mathrm{ORSV}^{\mathrm{E} 100 \mathrm{~A}}$, however, were diverse and ranged from approximately 130 to $460 \mathrm{~nm}$ (Fig. 3A and B), thus demonstrating aberrant particle assembly. Next, we performed a size-exclusion chromatography analysis to further analyze viral particles from infected plants. The results showed that $\mathrm{CP}$ of ORSV ${ }^{\mathrm{WT}}$ was primarily detected in high molecularweight fractions, suggesting that most of the CPs formed viral particles in infected plants (Fig. 4A, upper panel). In contrast, the $\mathrm{CP}$ of ORSV ${ }^{\mathrm{E} 100 \mathrm{~A}}$ was primarily detected in low molecular-weight fractions, and less $\mathrm{CP}^{\mathrm{E} 100 \mathrm{~A}}$ was detected in the high molecularweight fractions, suggesting that $\mathrm{CP}^{\mathrm{E} 100 \mathrm{~A}}$ is less efficient at particle assembly (Fig. 4A, lower panel).

Virus particle assembly is correlated with the CP-CP interaction. Therefore, $\mathrm{CP}$ self-interaction was evaluated using an in vitro pull-down assay. $\mathrm{CP}^{\mathrm{WT}}$-His or $\mathrm{CP}^{\mathrm{E} 100 \mathrm{~A}}$-His was used as bait to test the CP-CP binding ability with glutathione $S$-transferase (GST)-CP $\mathrm{CP}^{\mathrm{WT}}$ and GST-CPE100A . The data showed that GST-CP $\mathrm{CP}^{\mathrm{WT}}+\mathrm{CP}^{\mathrm{WT}}$-His has the strongest interaction in different concentrations of Triton X-100 relative to GST-CP ${ }^{\mathrm{WT}}+$ $\mathrm{CP}^{\mathrm{E} 100 \mathrm{~A}}$-His, GST-CP $\mathrm{C}^{\mathrm{E} 100 \mathrm{~A}}+\mathrm{CP}^{\mathrm{WT}}-\mathrm{His}$, and GST-CP $\mathrm{E}^{\mathrm{E} 100 \mathrm{~A}}+$ $\mathrm{CP}^{\mathrm{E} 100 \mathrm{~A}}$-His (Fig. 4B). This result demonstrated that the substitution of residue $\mathrm{E}^{100}$ with $\mathrm{A}^{100}$ altered the binding affinity of the CP subunits. In summary, our data indicated that $\mathrm{CP}^{\mathrm{E} 100 \mathrm{~A}}$ loses its ability to form viral particles of the correct size and, therefore, might result in the defective systemic movement of $\mathrm{ORSV}^{\mathrm{E} 100 \mathrm{~A}}$ in $N$. benthamiana. In addition, the $\mathrm{E}^{100} \mathrm{~A}$ substitution on the ORSV CP might alter the interaction between the $\mathrm{CP}$ and host components, resulting in deficiencies of systemic movement or viral infection.

\section{Integrated omics approach with an experimental validation for CP interaction study.}

In addition to viral particle assembly, the CP-host component interaction also plays an important role in viral infection and defense response (Li et al. 2005; Karran and Sanfaçon 2014). In this study, an integrated omics approach that combines the whole-transcriptome and proteome was used to
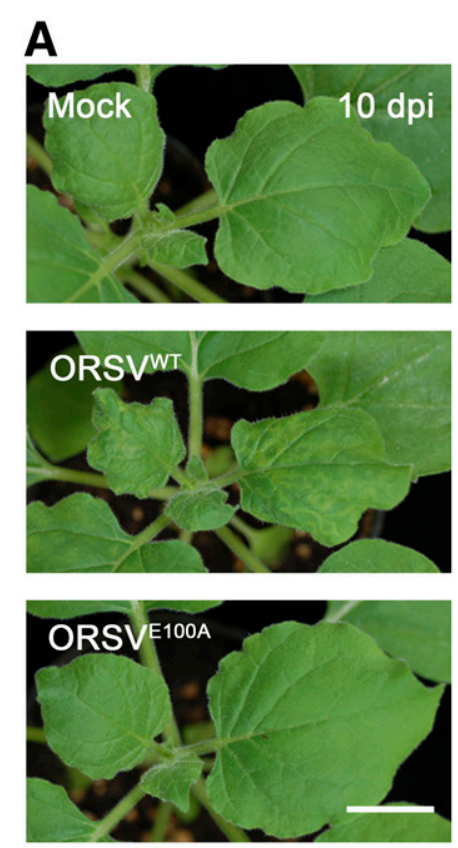

B

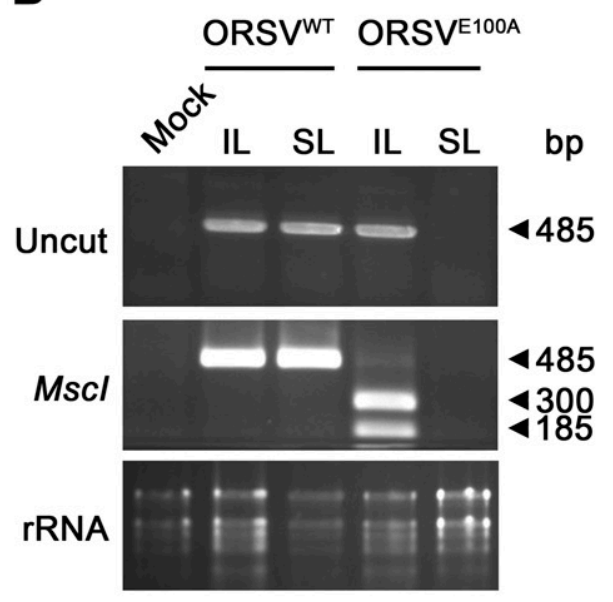

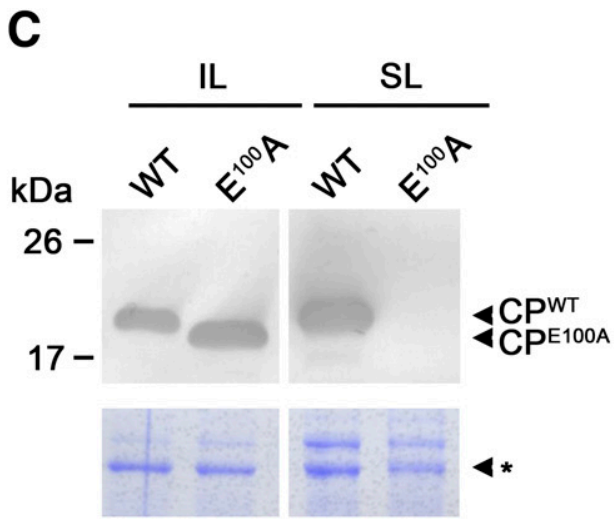

Fig. 2. The $\mathrm{E}^{100}$ residue of the Odontoglossum ringspot virus (ORSV) capsid protein (CP) contributes to viral infectivity on Nicotiana benthamiana. A, Symptoms of mock- and ORSV-inoculated $N$. benthamiana plants. Photographs were taken at 10 days postinoculation (dpi). Bar $=1 \mathrm{~cm}$. B, Reverse transcription-polymerase chain reaction (RT-PCR) and restriction fragment length polymorphism analysis of inoculated (IL) and systemic (SL) leaves from mock-, ORSV ${ }^{\mathrm{WT}}$-, and ORSV ${ }^{\mathrm{E} 100 \mathrm{~A}}$-infected plants at $10 \mathrm{dpi}$. The uncut (upper panel) and MscI-digested (middle panel) RT-PCR products of CP genes and rRNAs (lower panel) are shown. C, CP accumulation in IL and SL of mock-, ORSV ${ }^{\text {WT }}$ - and ORSV ${ }^{\text {E100A }}$-infected plants was analyzed by Western blot analysis with an anti-ORSV CP antibody at $10 \mathrm{dpi}$. Rubisco was used as the loading control (lower panel). 
identify the CP-IP and their expression profiles (Fig. 5A and B). The transcriptomic sequence provides a precise mass spectrum for proteomic predictions by bioinformatics (Fig. 5C). Finally, these candidate $\mathrm{CP}$-IP can be verified through experimental validation, including semiquantitative RT-PCR, in vitro binding assays, and VIGS (Fig. 5D).

\section{Whole-transcriptome analysis and gene expression of $N$. benthamiana.}

To obtain a comprehensive gene expression profile of $N$. benthamiana, healthy and ORSV ${ }^{\mathrm{WT}}$-infected plants were analyzed, based on their whole-transcriptome profiles, using NGS. We obtained 26,201,860 raw reads from healthy plants and 27,266,778 reads from ORSV ${ }^{\mathrm{WT}}$-infected plants (Fig. 5A). These reads were mixed for de novo assembly, and $84 \%$ of the reads were successfully assembled into 85,599 contigs. These contigs were analyzed using the basic local alignment search tool (BLAST) with an Arabidopsis thaliana coding sequence (CDS) database (TAIR 10) and an European Molecular Biology Laboratory (EMBL) CDS database for name-calling and open reading frame $(\mathrm{ORF})$ annotation. The annotation results identified 5,436 complete contigs (6\%) and 35,123 partial contigs (41\%) (Figs. 5A and 6A). All of the contig sequence information and annotation results were integrated into ContigViews to develop a $N$. benthamiana transcriptome database.

The 5,436 complete contigs from $N$. benthamiana were compared for similarities with Arabidopsis CDS. The lengths of the matched CDS between N. benthamiana and Arabidopsis are highly correlated $(R=0.993)$, and the majority of the genes were identical in length to their homologs in Arabidopsis (Fig. $6 \mathrm{~B}$ and $\mathrm{C}$ ). The average amino acid similarity was approximately $50 \%$ (Fig. 6D). In addition, 12,135 of 40,559 genes showed more than $50 \%$ coverage in the reference sequence
(Supplementary Table 1). Of 12,135 genes, 30\% showed twofold differential expression during ORSV infection (Fig. 7A). The gene set enrichment analysis (GSEA) results indicated that many genes were involved in metabolic processes, stress response, and chloroplast development (Table 1). Therefore, these results suggested that ORSV infection triggers the host defense response and interferes with chloroplast development.

Next, 40,559 N. benthamiana genes (including complete and partial genes) were used to predict the protein mass database and were then integrated into MASCOT for further proteomics analysis (Figs. 5C and 6A).

\section{Protein identification using the $N$. benthamiana transcriptome database.}

The coimmunoprecipitation and liquid chromatography-tandem mass spectrometry (LC-MS/MS) approaches were employed to identify the ORSV CP-IP (Fig. 5B). The results showed that CP coimmunoprecipitated with possible $\mathrm{CP}$-interacting host proteins from extracts of ORSV ${ }^{\mathrm{WT}}$ - and $\mathrm{ORSV}^{\mathrm{E} 100 \mathrm{~A}}$-infected plants (Fig. 8A). Entire lanes of the three coimmunoprecipitation products (healthy, ORSV ${ }^{\mathrm{WT}}$, and ORSV ${ }^{\mathrm{E} 100 \mathrm{~A}}$ ) were analyzed by LC-MS/ MS after in-gel digestion (Fig. 8A). The mass results were analyzed by MASCOT with the ContigViews $N$. benthamiana transcriptome database (Fig. 5B and C).

A total of 51 proteins correlated to the transcriptome contigs were identified from coimmunoprecipitation products of $\mathrm{CP}^{\mathrm{WT}}$ and $\mathrm{CP}^{\mathrm{E} 100 \mathrm{~A}}$ that were filtered to remove false positive proteins from the LC-MS/MS profile of healthy plants and were considered as the putative ORSV CP-IP (Tables 2 and 3). ORSV CP was among the proteins identified from both the $\mathrm{CP}^{\mathrm{WT}}$ - and $\mathrm{CP}^{\mathrm{E} 100 \mathrm{~A}}$-infected samples, indicating that the coimmunoprecipitation and LC-MS/ MS processes were successful (Fig. 8A). Most of the IP identified from the $\mathrm{CP}^{\mathrm{WT}}$ and $\mathrm{CP}^{\mathrm{E} 100 \mathrm{~A}}$ fractions were photosystem subunits,
A
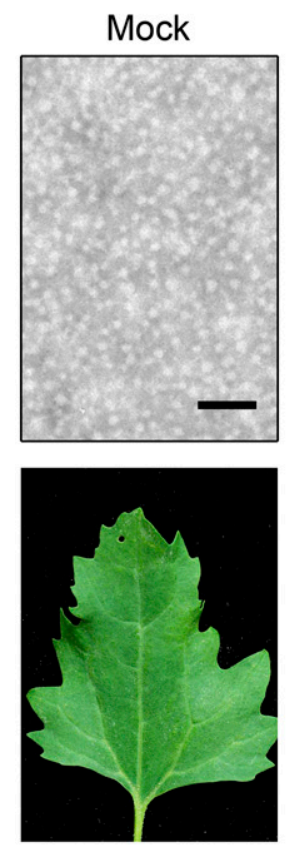
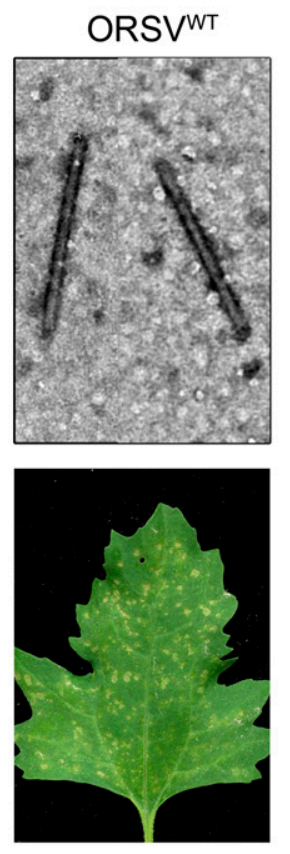
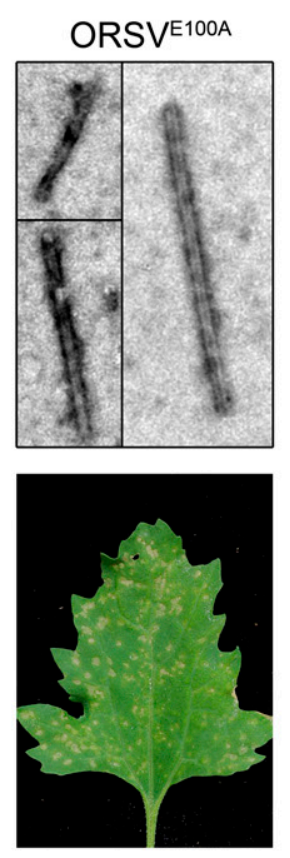

B
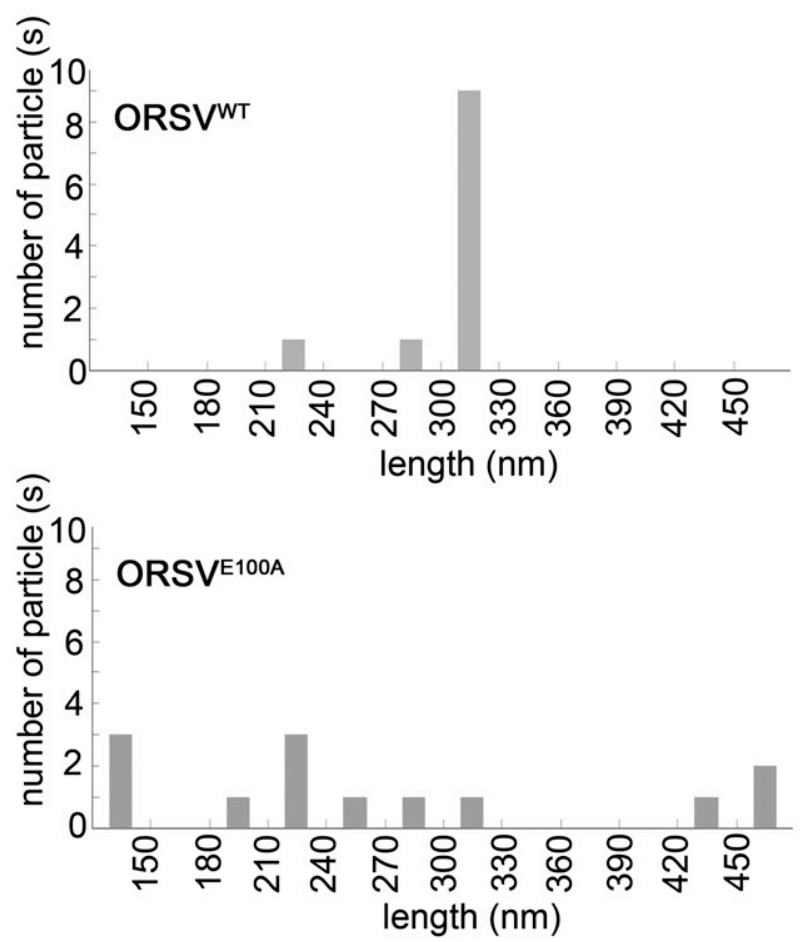

Fig. 3. Observation of Odontoglossum ringspot virus wild type (ORSV ${ }^{\mathrm{WT}}$ ) and ORSV ${ }^{\mathrm{E} 100 \mathrm{~A}}$ viral particles by immunosorbent electron microscopy (ISEM). A, Local lesion formation on mock- and ORSV-inoculated Chenopodium quinoa was observed at 4 days postinoculation. ISEM was performed with an anti-ORSV capsid protein antibody. Antibody-decorated viral particles of ORSV ${ }^{\mathrm{WT}}$ and $\mathrm{ORSV}^{\mathrm{E} 100 \mathrm{~A}}$ derived from inoculated $C$. quinoa are shown. Bar $=100 \mathrm{~nm}$. B, The particle length distribution of ORSV ${ }^{\mathrm{WT}}$ (upper) and $\mathrm{ORSV}^{\mathrm{E} 100 \mathrm{~A}}$ (lower) virions. 
suggesting that ORSV might affect the chloroplasts through $\mathrm{CP}-$ photosystem subunit interactions (Table 2).

CPWT-IP.

In this study, we focused on the $\mathrm{CP}^{\mathrm{WT}}$-IP, in which the real viral infection can be reflected. Thirty $C P^{W T}-I P$ genes with differential in silico expression between mock- and ORSVinfected plants were identified (Table 3). For NbRCA (NBOR457), whose ortholog in Arabidopsis is a ribulose1,5-bisphosphate carboxylase (Rubisco) activase, expression was down-regulated in ORSV-infected plants (Fig. 7Bi and D; Table 3), whereas the expression of NbIIL1 (NBOR18678) was upregulated (Fig. 7Bii and D; Table 3). Both orthologs in Arabidopsis have also been reported to be involved in photosystems (BoexFontvieille et al. 2014; Portis 2003; Sureshkumar et al. 2009).

The orthologous genes of NbGOXI (NBOR1162) and NbSHM1.1 (NBOR327) in Arabidopsis have been demonstrated to be involved in oxygen species metabolic pathways (Chern et al. 2013; Fahnenstich et al. 2008; Zhou et al. 2012). Both genes were down-regulated in ORSV-infected plants (Fig. 7Biii and iv and D;

A

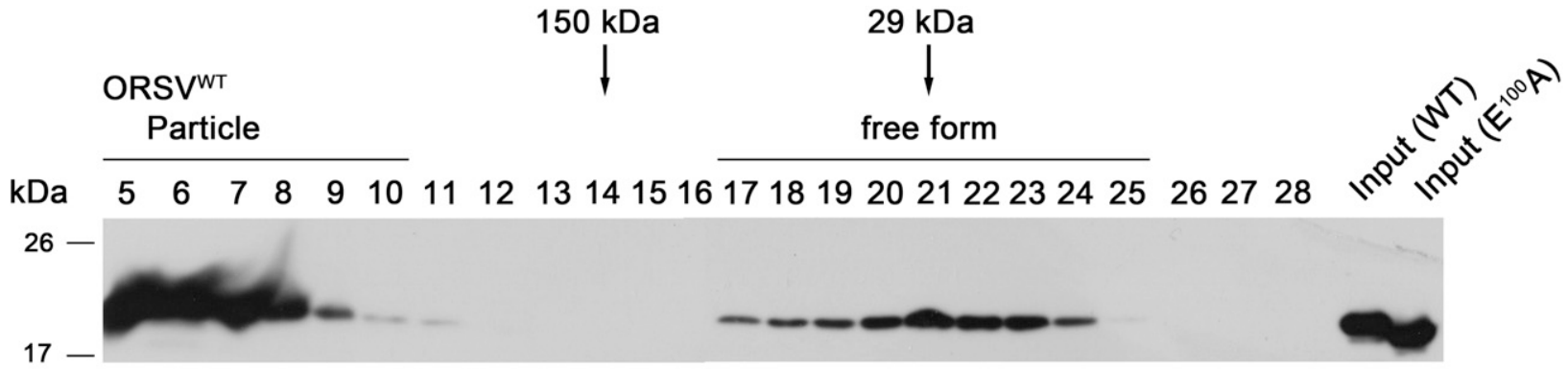

ORSVE100A

kDa $\quad 5 \quad 6 \quad 7 \quad 8 \quad 910111213141516171819202122232425262728$ री

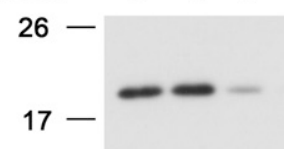

B

B Pull down

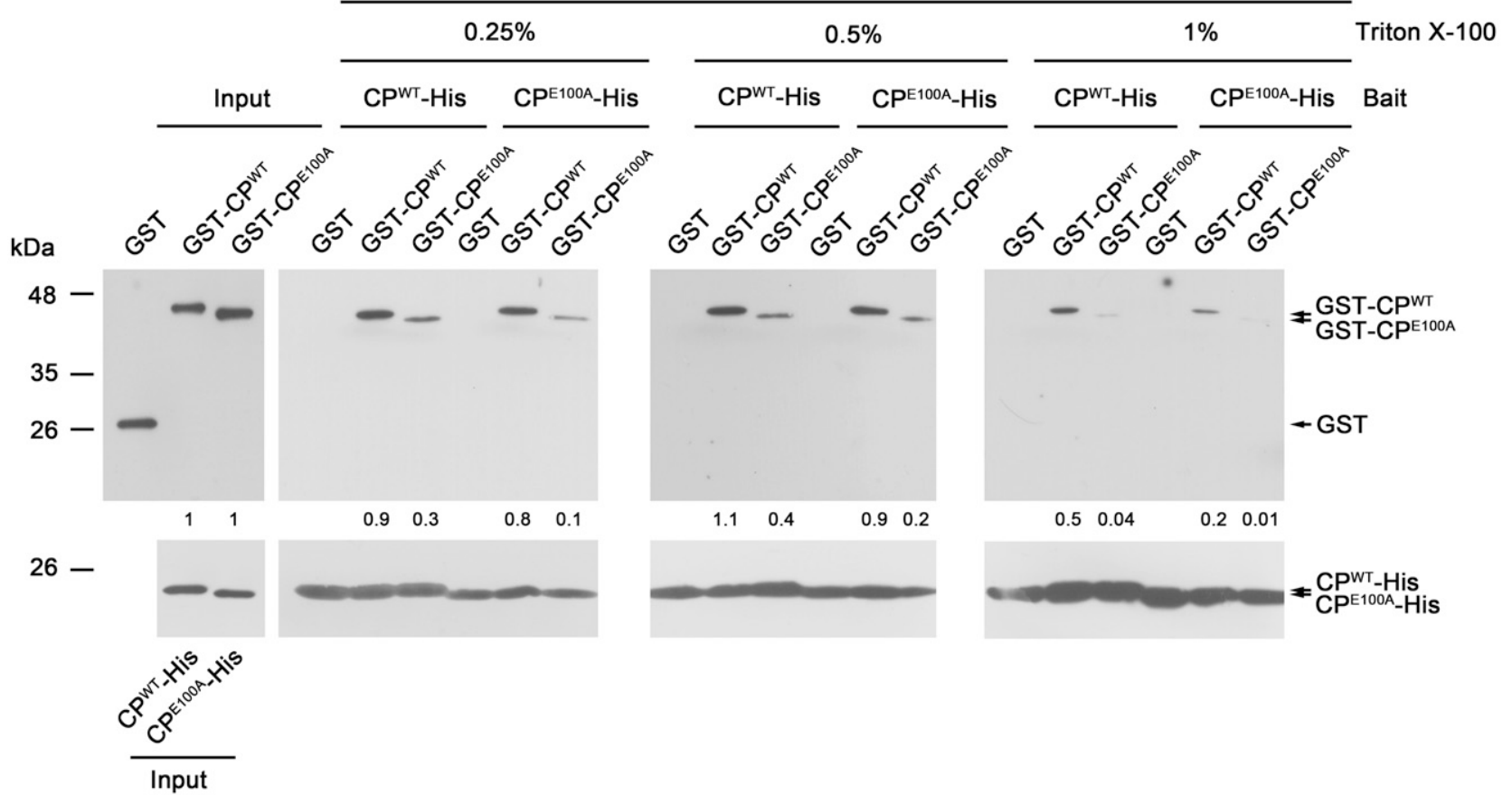

Fig. 4. Evaluation of viral particle assembly of Odontoglossum ringspot virus wild type (ORSV ${ }^{\mathrm{WT}}$ ) and $\mathrm{ORSV}^{\mathrm{E} 100 \mathrm{~A}}$. A, The capsid protein (CP) size distribution of $\mathrm{ORSV}^{\mathrm{WT}}$ and $\mathrm{ORSV}^{\mathrm{E} 100 \mathrm{~A}}$ in planta was analyzed using size-exclusion chromatography. The total protein extracts from ORSV ${ }^{\mathrm{WT}}$ - and $\mathrm{ORSV}^{\mathrm{E} 100 \mathrm{~A}}$-infected Nicotiana benthamiana were size-fractionated on a gel filtration column. Fractions were analyzed by Western blot analysis with an antiORSV CP antibody. The numbers on the top of the panel indicate the fractions. The molecular sizes of the standards are indicated with arrows. B, In vitro CP$\mathrm{CP}$ interaction assay of ORSV CP ${ }^{\mathrm{WT}}$ and $\mathrm{CP}^{\mathrm{E} 100 \mathrm{~A}}$. Glutathione $S$-transferase (GST)-CP ${ }^{\mathrm{WT}}$ or GST-CP $\mathrm{E}^{\mathrm{E} 100 \mathrm{~A}}$ and CP $\mathrm{CP}^{\mathrm{WT}}-\mathrm{His}$ or $\mathrm{CP}^{\mathrm{E} 100 \mathrm{~A}}$-His were assayed for in vitro $\mathrm{CP}-\mathrm{CP}$ interaction using a pull-down assay. The bait $\mathrm{CP}\left(\mathrm{CP}^{\mathrm{WT}}\right.$-His or $\mathrm{CP}^{\mathrm{E} 100 \mathrm{~A}}$-His) was pulled down with Ni-NTA, and Western blot analysis was performed with an anti-GST polyclonal antibody. Different stringencies were created using various concentrations of Triton X-100 $(0.25 \%, 0.5 \%$, or $1 \%)$. The inputs $\left(\mathrm{CP}^{\mathrm{WT}}\right.$-His, $\mathrm{CP}^{\mathrm{E} 100 \mathrm{~A}}$-His, GST, GST-CP ${ }^{\mathrm{WT}}$, and GST-CP $\mathrm{CP}^{\mathrm{E} 100 \mathrm{~A}}$ ) used in this study were verified by Western blot analysis with anti-His or anti-GST antibodies. The numbers indicate the relative fold change of pulled-down $\mathrm{CP}$ to the $\mathrm{CP}^{\mathrm{WT}}$ or $\mathrm{CP}^{\mathrm{E} 100 \mathrm{~A}}$ of inputs. 
Table 3). In contrast, NbNPC2 (NBOR6197), whose orthologs in Arabidopsis have been shown to be involved in the biotic stress response (Slaughter et al. 2012; Pokotylo et al. 2013), was up-regulated in ORSV-infected plants (Fig. 7Bv and D; Table 3). Moreover, NbPIP1;4 (NBOR145), which is a member of the plasma membrane-intrinsic protein (PIP) family in Arabidopsis and involved in the response to chilling stress (Lee et al. 2012), was down-regulated in ORSV-infected plants (Fig. 7Bvi and D; Table 3).

In addition to the in silico expression of $C P^{W T}-I P$, in vivo RNA transcript expressions between mock and ORSV-infected plants were also confirmed by semiquantitative RT-PCR (Fig. 7D). NbRCA, NbSHM1.1, and NbPIP1;4 were down-regulated in ORSV-infected plants, whereas NbNPC2 and NbIIL1 were up-regulated. These results are consistent with the in silico profiles (Fig. 7B and D). The $N b G O X 1$ gene was not detected by semiquantitative RT-PCR.

Moreover, the $\mathrm{CP}^{\mathrm{WT}}$-IP were evaluated for their interaction with $\mathrm{CP}^{\mathrm{WT}}$. The pEXP5-CT/TOPO TA expression system (Invitrogen) and the Expressway Cell-Free E. coli Expression system (Invitrogen) were used for cloning of $C P^{W T}-I P$ genes and in vitro recombinant protein expression. The $N b G O X 1$, NbIIL1, NbNPC2, and NbRCA genes (partial ORF; sequence refers to the amino acids 129 to 270 of AtRCA) were successfully cloned and expressed by in vitro transcription and translation (Fig. 9A). Except for NbRCA-His, the CP ${ }^{\mathrm{WT}}$-IP showed interaction

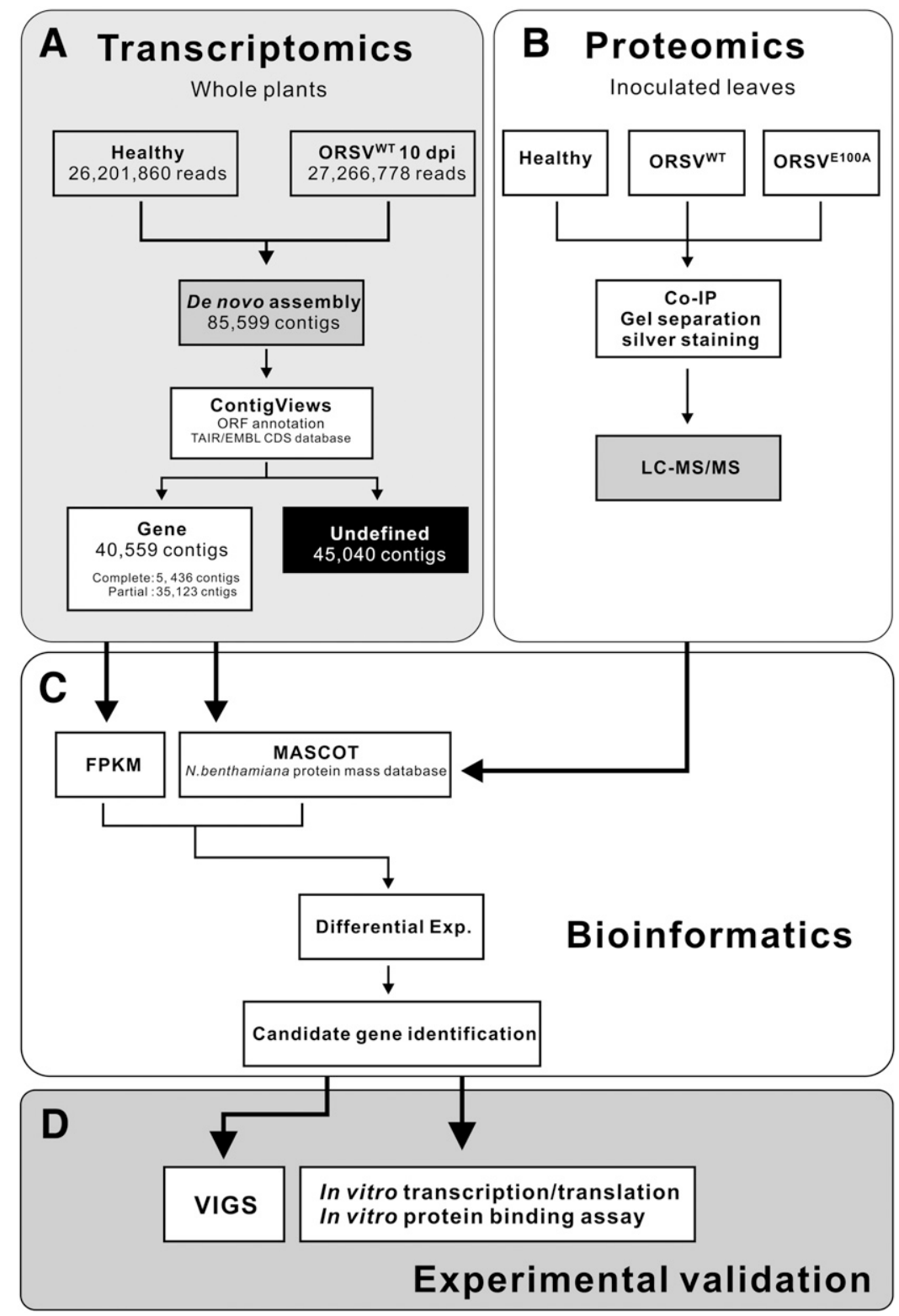

Fig. 5. Next-generation sequencing was used in the proteomics workflow and whole-transcriptome assays. A, Whole-transcriptome analysis pipeline. Healthy and Odontoglossum ringspot virus wild type $\left(\mathrm{ORSV}^{\mathrm{WT}}\right)$-infected Nicotiana benthamiana plants at 10 day postinoculation were used for whole-transcriptome analysis by deep sequencing. The de novo assembly utilized mixed reads from two samples to generate $N$. benthamiana transcript contigs. Gene annotation and open reading frame finding was predicted using the ContigViews web server (Liu et al. 2014), and the amino acid sequences of these genes were used for protein mass prediction by MASCOT. B, Healthy, $\mathrm{ORSV}^{\mathrm{WT}}{ }_{-}$, and $\mathrm{ORSV}^{\mathrm{E} 100 \mathrm{~A}}$-infected $N$. benthamiana plants were used for proteomics analysis. The ORSV CP-interacting proteins (CP-IP) were isolated by immunoprecipitation with anti-ORSV CP antibodies from the total protein extracts. These co-immunoprecipitated proteins were separated by gel electrophoresis and were stained with the silver straining method. These elutes were analyzed using liquid chromatography-tandem mass spectrometry methods. C, The mass results were compared with the specific $N$. benthamiana mass database by MASCOT for the protein identification. The CP-IP were verified using the transcriptome database to identify the candidate genes involved in ORSV infection. D, The candidate CP-IP were evaluated for CP-binding ability and gene function through experimental approaches, including in vitro binding assay and virus-induced gene silencing (VIGS). 
with $\mathrm{CP}^{\mathrm{WT}}$ in vitro, confirming the coimmunoprecipitation proteomics results (Fig. 9B). In addition, variations of the prey signal intensities of the coimmunoprecipitation imply different binding affinities between $\mathrm{CP}^{\mathrm{WT}}$ and $\mathrm{CP}^{\mathrm{WT}}$-IP (Fig. 9B). However, green fluorescent protein $(\mathrm{GFP})+\mathrm{GST}-\mathrm{CP}^{\mathrm{WT}}$ did not show an interaction and was used as a negative control (Fig. 9C). The lack of interacting signal between GST-CP ${ }^{\mathrm{WT}}$ and NbRCA-His (Fig. 9B) may have been caused by the lower input of $\mathrm{Nb}$ RCA-His (Fig. 9A) or the lack of a $\mathrm{CP}^{\mathrm{WT}}$-interacting domain in the partial NbRCA protein.

The other $\mathrm{CP}^{\mathrm{WT}}$-IP, such as NbIBS1 (NBOR22975), NbFIB4 (NBOR6354), NbCNGC1 (NBOR12131), NbAGT1 (NBOR316), NbVCL1 (NBOR48019), and NbSK21 (NBOR4906) are listed in Table 3. Their orthologous genes in Arabidopsis have been reported to be involved in biotic stress response, photosystems, ion channels, nutrition transport, vacuole development, and protein degradation (Hicks et al. 2004; Pokotylo et al. 2013; Singh et al. 2010; Slaughter et al. 2012; Wang et al. 2013; Zhang et al. 2013; Zhao et al. 2003). NbFLN1 (NBOR16452) and $N b O R C 2$ (NBOR45173) interact with $\mathrm{CP}^{\mathrm{WT}}$ and their mRNA expressions were up-regulated in infected plants (Table 3). Moreover, a helicase-SANT-associated domain protein (NBOR6246) was identified and shown to interact with $\mathrm{CP}^{\mathrm{WT}}$ (Table 3). These orthologous genes in Arabidopsis play a role in RNA expression, cell division, and nucleic acid binding, respectively (Bell and Dutta 2002; Gilkerson et al. 2012). The remaining $15 \mathrm{CP}^{\mathrm{WT}}$ - and $13 \mathrm{CP}^{\mathrm{E} 100 \mathrm{~A}}$-IP that have not been characterized or have unclear functions are listed in Supplementary Table 2.
NbPI2 was enriched in $\mathrm{CP}^{\mathrm{E} 100 \mathrm{~A}}$

coimmunoprecipitation products.

A 24-kDa protein was observed in the coimmunoprecipitation reaction of $\mathrm{CP}^{\mathrm{E} 100 \mathrm{~A}}$, whereas a weak band was found in the reaction of $\mathrm{CP}^{\mathrm{WT}}$ (Fig. 8A). After protein identification of the single band using LC-MS/MS, NbPI2 (NBOR2273), a $N$. benthamiana protein similar to a putative proteinase inhibitor of N. glutinosa (AAF15901) (Park et al. 2000), was identified (Table 2). A homologous gene, NbPI1 (NBOR2375), was identified from the transcriptome database based on $\mathrm{NbPI} 2$ sequence similarity, and both genes were up-regulated in ORSV-infected plants (Fig. 7C and D). This band was not observed in the input extracts of either $\mathrm{CP}$, suggesting that it was enriched during the coimmunoprecipitation process. Furthermore, the results of the in vitro binding assay indicated that ORSV CP has a strong binding affinity to NbPI2 (Fig. 9D). However, a weak coimmunoprecipitation signal of NbPI1 was observed at longer exposure times (Fig. 9D), suggesting that ORSV CP prefers to bind NbPI2 rather than NbPI1.

Based on the results of the large-scale protein identification, the divalent $472.25 \mathrm{~m} / \mathrm{z}$ peptide of NbPI 2 was enriched in the $\mathrm{CP}^{\mathrm{E} 100 \mathrm{~A}}$ sample on the extracted ion chromatogram (Fig. 8B, the bottom-right panel shows a peak at a retention time of 27.12 min for $\mathrm{CP}^{\mathrm{E} 100 \mathrm{~A}}$ ), whereas it was present in smaller amounts in the $\mathrm{CP}^{\mathrm{WT}}$ sample and was absent in the mock control sample (Fig. 8B, the middle and upper right panels show a peak at a retention time of $27.30 \mathrm{~min}$ for $\mathrm{CP}^{\mathrm{WT}}$ and none for mock sample), indicating that NbPI2 is associated with ORSV
A
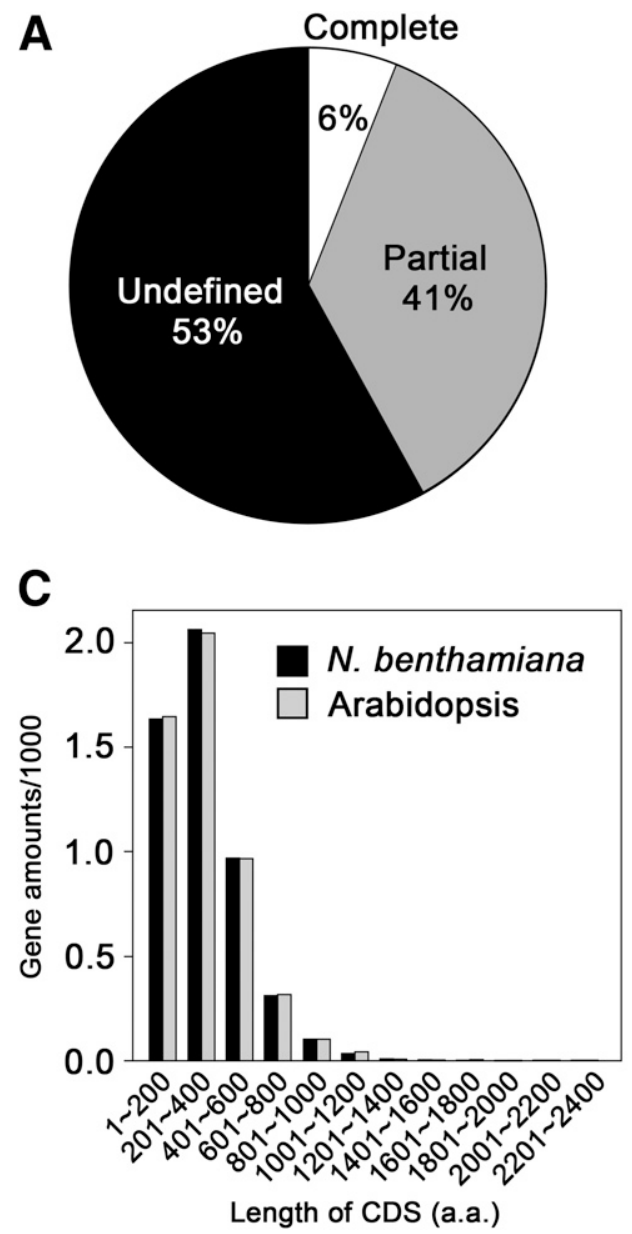

B

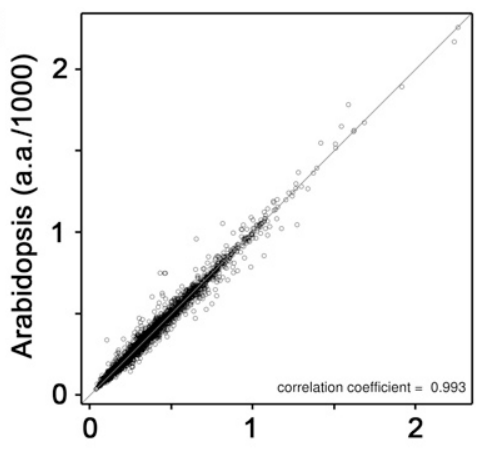

N. benthamiana (a.a./1000)

D

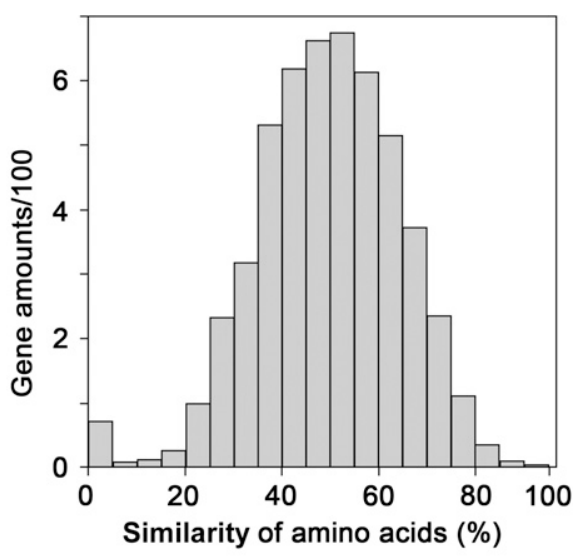

Fig. 6. Statistical analysis of gene similarity between Nicotiana benthamiana and Arabidopsis. A, Pie chart shows the percentages of complete genes, partial genes, and undefined contigs. B, Scatter plot of the coding sequence (CDS) lengths of $N$. benthamiana versus those of Arabidopsis. C, The length distribution comparison and D, amino acid similarity of the CDS of Arabidopsis and N. benthamiana are shown. 

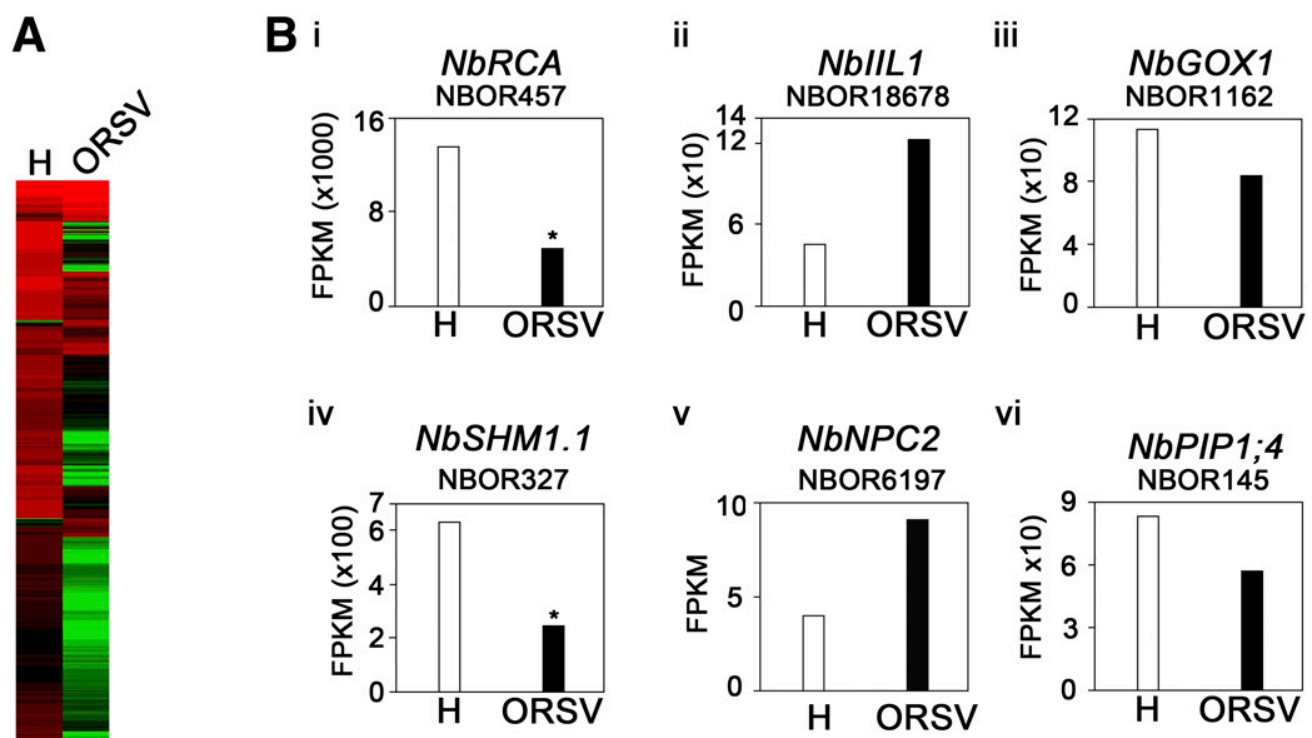

C
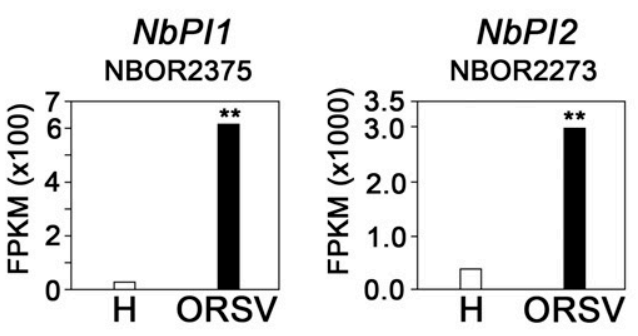

5.3
2.8
0.7
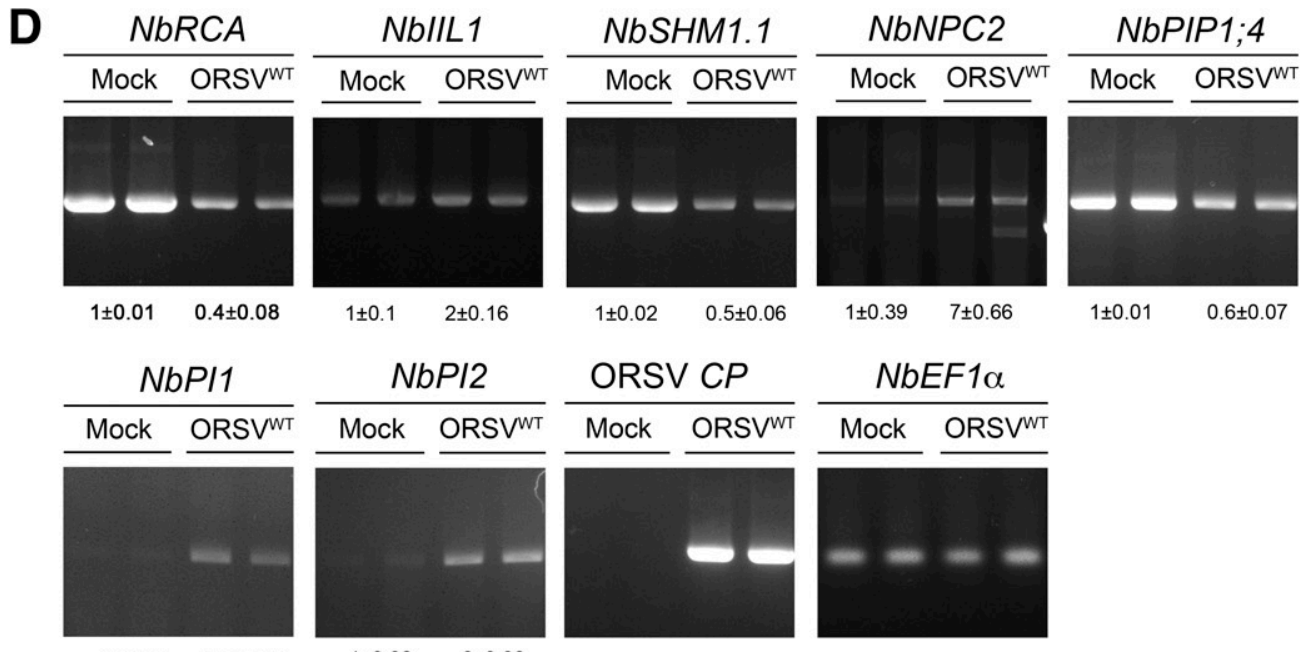

Fig. 7. Comparison of the gene expression patterns between healthy and Odontoglossum ringspot virus wild type (ORSV ${ }^{\mathrm{WT}}$ )-infected Nicotiana benthamiana plants using next-generation sequencing. A, The gene expression patterns of healthy and ORSV ${ }^{\mathrm{WT}}$-infected $N$. benthamiana. B, Comparison of the gene expression levels of ORSV CP ${ }^{\mathrm{WT}}$-interacting proteins $\left(\mathrm{CP}^{\mathrm{WT}}\right.$-IP). The FPKM (fragments per kilobase of transcript per million mapped reads) value was used to indicate the gene expression levels in healthy and ORSV-infected $N$. benthamiana. C, NbPI1 and NbPI2 gene expression levels. The FPKM levels of ORSV-infected plants were significantly different from healthy plants, based on DESeq analysis. A single asterisk (*) indicates $P$ value $<0.05$, double asterisks $(* *)$ indicate $P$ value $<0.01$. D, The validation of $C P^{W T}$-IP gene expressions between mock- and ORSV-infected plants by semiquantitative reverse transcription-polymerase chain reaction. The EFl $\alpha$ gene served as an internal control. Numbers refer to the signal intensity of gene expression levels after normalization against the loading control $(n=3)$. The $C P^{W T}-I P$ gene level in the mock sample was arbitrarily set as 1.0. 
$\mathrm{CP}$ and especially with $\mathrm{CP}^{\mathrm{E} 100 \mathrm{~A}}$. The appearance of the divalent $493.25 \mathrm{~m} / \mathrm{z}$ peptide of ORSV CP in both the $\mathrm{CP}^{\mathrm{WT}}$ and $\mathrm{CP}^{\mathrm{E} 100 \mathrm{~A}}$ samples (Fig. 8B, middle and bottom left panels) but not the mock controls also ensured that the coimmunoprecipitation and LC-MS/MS procedures were successful. These data confirmed the tight association between $\mathrm{CP}^{\mathrm{E} 100 \mathrm{~A}}$ and NbPI2 of $N$. benthamiana in vivo.

To evaluate the association between NbPI2 and ORSV infection, we first examined the expression pattern of $\mathrm{NbPI2}$ in healthy and ORSV-infected plants. The results of a semiquantitative RT-PCR analysis with $N b P I 2$ gene-specific primers showed that NbPI2 mRNA was highly expressed in ORSV ${ }^{\mathrm{WT}}$ and $\mathrm{ORSV}^{\mathrm{E} 100 \mathrm{~A}}$-infected $N$. benthamiana at $10 \mathrm{dpi}$ compared with the healthy or mock-inoculated plants (Fig. 8C). A weaker signal was detected in mock-inoculated plants, which was most

Table 1. Significant gene ontology (GO) terms from the gene set enrichment analysis for the 12,135 genes that showed twofold differential expression during Odontoglossum ringspot virus (ORSV) infection (false discovery rate $[\mathrm{FDR}] \leq 10^{-10}$ )

\begin{tabular}{|c|c|c|c|}
\hline GO accession & Type $^{\mathbf{a}}$ & Term & FDR \\
\hline GO:0009987 & $\mathrm{P}$ & Cellular process & $8.30 \mathrm{E}-40$ \\
\hline GO:0009791 & $\mathrm{P}$ & Postembryonic development & $9.20 \mathrm{E}-38$ \\
\hline GO:0008152 & $\mathrm{P}$ & Metabolic process & $6.70 \mathrm{E}-32$ \\
\hline GO:0044237 & $\mathrm{P}$ & Cellular metabolic process & $7.80 \mathrm{E}-24$ \\
\hline GO:0050896 & $\mathrm{P}$ & Response to stimulus & $1.00 \mathrm{E}-23$ \\
\hline GO:0044238 & $\mathrm{P}$ & Primary metabolic process & $2.20 \mathrm{E}-22$ \\
\hline GO:0032501 & $\mathrm{P}$ & Multicellular organismal process & $4.20 \mathrm{E}-20$ \\
\hline GO:0007275 & $\mathrm{P}$ & $\begin{array}{l}\text { Multicellular organismal } \\
\text { development }\end{array}$ & $2.30 \mathrm{E}-19$ \\
\hline GO:0051179 & $\mathrm{P}$ & Localization & $3.00 \mathrm{E}-18$ \\
\hline GO:0051234 & $\mathrm{P}$ & Establishment of localization & $1.40 \mathrm{E}-17$ \\
\hline GO:0032502 & $\mathrm{P}$ & Developmental process & $2.30 \mathrm{E}-17$ \\
\hline GO:0006810 & $\mathrm{P}$ & Transport & $4.10 \mathrm{E}-17$ \\
\hline GO:0048856 & $\mathrm{P}$ & Anatomical structure development & $9.20 \mathrm{E}-16$ \\
\hline GO:0006950 & $\mathrm{P}$ & Response to stress & $5.30 \mathrm{E}-15$ \\
\hline GO:0044262 & $\mathrm{P}$ & $\begin{array}{l}\text { Cellular carbohydrate metabolic } \\
\text { process }\end{array}$ & $2.20 \mathrm{E}-13$ \\
\hline GO:0034641 & $\mathrm{P}$ & $\begin{array}{l}\text { Cellular nitrogen compound } \\
\text { metabolic process }\end{array}$ & $8.00 \mathrm{E}-13$ \\
\hline GO:0009628 & $\mathrm{P}$ & Response to abiotic stimulus & $8.20 \mathrm{E}-13$ \\
\hline GO:0042221 & $\mathrm{P}$ & Response to chemical stimulus & $1.40 \mathrm{E}-12$ \\
\hline GO:0051716 & $\mathrm{P}$ & Cellular response to stimulus & $5.20 \mathrm{E}-12$ \\
\hline GO:0003006 & $\mathrm{P}$ & $\begin{array}{l}\text { Reproductive developmental } \\
\text { process }\end{array}$ & $9.80 \mathrm{E}-11$ \\
\hline GO:0033036 & $\mathrm{P}$ & Macromolecule localization & $1.60 \mathrm{E}-10$ \\
\hline GO:0005623 & $\mathrm{C}$ & Cell & $1.10 \mathrm{E}-81$ \\
\hline GO:0044464 & $\mathrm{C}$ & Cell part & $1.10 \mathrm{E}-81$ \\
\hline GO:0005622 & $\mathrm{C}$ & Intracellular & $8.70 \mathrm{E}-67$ \\
\hline GO:0044424 & $\mathrm{C}$ & Intracellular part & $2.10 \mathrm{E}-66$ \\
\hline GO:0005737 & $\mathrm{C}$ & Cytoplasm & $1.80 \mathrm{E}-57$ \\
\hline GO:0043229 & $\mathrm{C}$ & Intracellular organelle & $3.30 \mathrm{E}-56$ \\
\hline GO:0043226 & $\mathrm{C}$ & Organelle & $3.30 \mathrm{E}-56$ \\
\hline GO:0044444 & $\mathrm{C}$ & Cytoplasmic part & $2.00 \mathrm{E}-54$ \\
\hline GO:0016020 & $\mathrm{C}$ & Membrane & $3.10 \mathrm{E}-52$ \\
\hline GO:0043227 & $\mathrm{C}$ & Membrane-bounded organelle & $1.30 \mathrm{E}-48$ \\
\hline GO:0043231 & $\mathrm{C}$ & $\begin{array}{l}\text { Intracellular membrane-bounded } \\
\text { organelle }\end{array}$ & $3.50 \mathrm{E}-48$ \\
\hline GO:0005886 & $\mathrm{C}$ & Plasma membrane & $4.60 \mathrm{E}-39$ \\
\hline GO:0044422 & $\mathrm{C}$ & Organelle part & $1.00 \mathrm{E}-23$ \\
\hline GO:0044446 & $\mathrm{C}$ & Intracellular organelle part & $1.30 \mathrm{E}-23$ \\
\hline GO:0032991 & $\mathrm{C}$ & Macromolecular complex & $2.40 \mathrm{E}-14$ \\
\hline GO:0009536 & $\mathrm{C}$ & Plastid & $9.30 \mathrm{E}-14$ \\
\hline GO:0043232 & $\mathrm{C}$ & $\begin{array}{l}\text { Intracellular non-membrane } \\
\text { bounded organelle }\end{array}$ & $1.50 \mathrm{E}-13$ \\
\hline GO:0043228 & $\mathrm{C}$ & Non-membrane bounded organelle & $1.50 \mathrm{E}-13$ \\
\hline GO:0043234 & $\mathrm{C}$ & Protein complex & $1.30 \mathrm{E}-12$ \\
\hline GO:0005739 & $\mathrm{C}$ & Mitochondrion & $4.00 \mathrm{E}-12$ \\
\hline GO:0005829 & $\mathrm{C}$ & Cytosol & $1.20 \mathrm{E}-11$ \\
\hline GO:0009507 & $\mathrm{C}$ & Chloroplast & $1.20 \mathrm{E}-11$ \\
\hline GO:0005634 & $\mathrm{C}$ & Nucleus & $4.50 \mathrm{E}-10$ \\
\hline
\end{tabular}

${ }^{\mathrm{a}} \mathrm{P}=$ biological processes, $\mathrm{C}=$ cellular components, $\mathrm{M}=$ molecular functions. likely because $N b P I 2$ was also induced by wounding (Fig. $8 \mathrm{C}$ ), indicating that NbPI2 is an ORSV- or wound-induced gene.

\section{Knock-down of $N b P I 1$ and $N b P I 2$ by VIGS.}

For the NbPI1 and NbPI2 functional assay, TRV-NbPI ${ }^{\mathrm{c}}$, which is Tobacco rattle virus containing the conserved sequences of $\mathrm{NbPII}$ and $\mathrm{NbPI2}$, was used for VIGS of $N b P I 1$ and NbPI2 expression in N. benthamiana plants. The TRV-NbPI ${ }^{\mathrm{c}}$-infected plants did not induce NbPII and NbPI2 expression when infected with ORSV, whereas ORSV-infected or TRV + ORSV mix-infected plants had highly induced NbPI1 and NbPI2 expression (Fig. 10A),

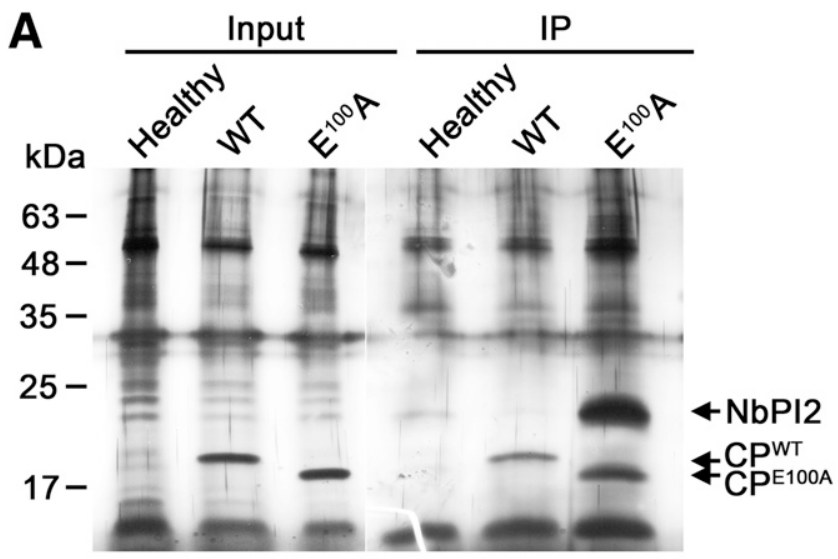

B
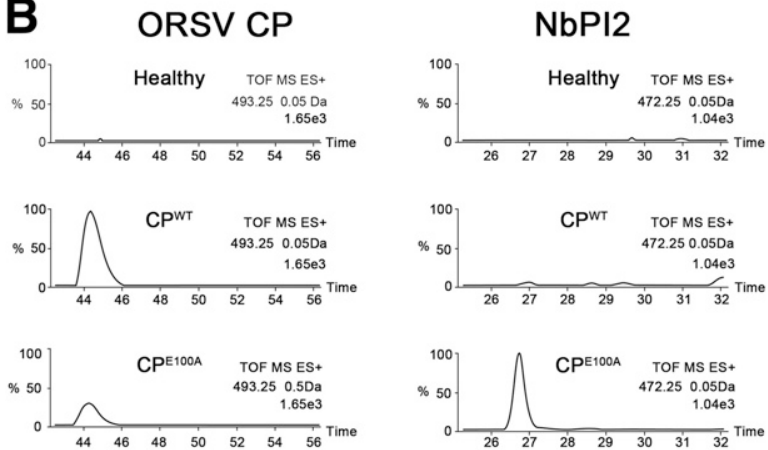

C

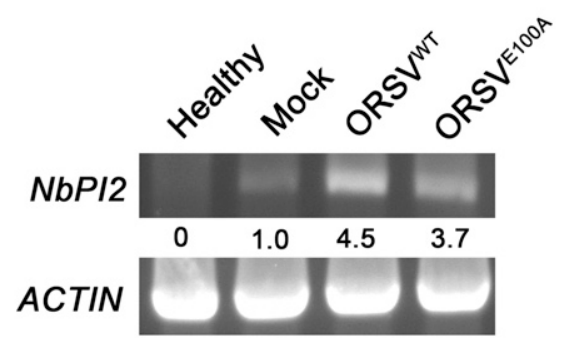

Fig. 8. Identification of Odontoglossum ringspot virus (ORSV) capsid protein-interacting host proteins (CP-IP) by coimmunoprecipitation. A, Silver staining of the coimmunoprecipitation products from the extracts of healthy, $\mathrm{ORSV}^{\mathrm{WT}}$ - or ORSV ${ }^{\mathrm{E} 100 \mathrm{~A}}$-infected plants (right panel). The arrow indicates the NbPI2 protein, which is specifically associated with $\mathrm{CP}^{\mathrm{E} 100 \mathrm{~A}}$. The original plant extracts were also stained as input controls (left panel). B, Extracted ion chromatograms of ORSV CP $(\mathrm{m} / \mathrm{z}=493.25)$ (left panels) and NbPI2 $(\mathrm{m} / \mathrm{z}=472.25)$ (right panels). The horizontal axis represents the retention times in liquid chromatography, and the vertical axis indicates the signal intensity. C, Expression of the NbPI2 gene was induced during ORSV infection. The semiquantitative reverse transcription-polymerase chain reaction of RNA from healthy, mock-, ORSV ${ }^{\mathrm{WT}}-$, and ORSVE100A inoculated Nicotiana benthamiana at 10 days postinoculation. The ACTIN gene served as an internal control. Numbers refer to signal intensity of NbPI2 expression levels after normalization against the loading control. The NbPI2 level in mock sample was arbitrarily set as 1.0. 
suggesting that $N b P I 1$ and $N b P I 2$ were silenced by TRV-NbPI ${ }^{\mathrm{c}}$. However, the amount of ORSV did not significantly change in TRV-NbPI ${ }^{c}$ VIGS plants compared with TRV-infected plants (Fig. 10B), suggesting that the loss-of-function of NbPI1 and NbPI2 did not interfere with ORSV infection. However, we cannot exclude the synergistic effects produced by TRV and ORSV coinfection in the same plants because they resulted in the high amounts of ORSV in TRV-NbPI ${ }^{\mathrm{c}}$ VIGS plants. In summary, these data indicated that $\mathrm{NbPII}$ and $\mathrm{NbPI} 2$ might be involved in the plant defense response against ORSV infection. Determining the precise function of NbPI1 and NbPI2, however, will require further investigation.

\section{DISCUSSION}

\section{$E^{100}$ is essential for the CP-CP interaction}

in particle assembly.

In this study, we created an $\mathrm{ORSV}^{\mathrm{E} 100 \mathrm{~A}}$ mutant virus that lost its systemic movement ability in $N$. benthamiana, and this virus also contained a distinct $M s c$ I RFLP marker and a unique $\mathrm{CP}^{\mathrm{E} 100 \mathrm{~A}}$ size. The $\mathrm{E}^{100}$ residue of the ORSV CP is a conserved amino acid in the genus Tobamovirus, suggesting that the $\mathrm{E}^{100}$ reside plays an important role in the virus life cycle. The data from ISEM and size-exclusion chromatography analyses revealed the defective assembly of viral particles in $\mathrm{ORSV}^{\mathrm{E} 100 \mathrm{~A}}$, indicating that an intact virus particle is necessary for ORSV systemic movement. This finding is consistent with previous studies in which the encapsidation of tobamoviruses was shown to be important for viral systemic movement (Dawson et al. 1988; Saito et al. 1990; Siegel et al. 1962; Takamatsu et al. 1987). In addition, the $\mathrm{CP}^{\mathrm{WT}}-\mathrm{CP}^{\mathrm{WT}}$ selfinteraction is much stronger than the $\mathrm{CP}^{\mathrm{WT}}-\mathrm{CP}^{\mathrm{E} 100 \mathrm{~A}}$ or $\mathrm{CP}^{\mathrm{E} 100 \mathrm{~A}}-\mathrm{CP}^{\mathrm{E} 100 \mathrm{~A}}$ interaction. In $\mathrm{TMV}$, the $\mathrm{CP}^{\mathrm{T} 42 \mathrm{~W}}$ mutant showed an altered CP-CP interaction, which resulted in the abnormal aggregation of virus particles in vivo (Bendahmane et al. 1997). Therefore, the $\mathrm{E}^{100}$ residue of the ORSV CP might affect the structure of viral particles by changing the $\mathrm{CP}-\mathrm{CP}$ interaction affinity.

Table 2. Wild-type capsid protein $\left(\mathrm{CP}^{\mathrm{WT}}\right)$ - and $\mathrm{CP}^{\mathrm{E} 100 \mathrm{~A}}$-interacting proteins

\begin{tabular}{|c|c|c|c|c|c|c|c|c|}
\hline \multirow[b]{2}{*}{ Gene } & \multirow[b]{2}{*}{ Contigs ID ${ }^{\mathbf{a}}$} & \multirow[b]{2}{*}{ Ref ID $^{b}$} & \multirow[b]{2}{*}{ Description } & \multicolumn{2}{|c|}{ Score $^{\mathrm{c}}$} & \multirow[b]{2}{*}{$\operatorname{Mass}(D a)^{d}$} & \multicolumn{2}{|c|}{ FPKM $^{\mathrm{e}}$} \\
\hline & & & & WT & $\mathrm{E}^{100} \mathrm{~A}$ & & Mock & ORSV \\
\hline NbPSAE2 & NBOR690 & AT2G20260 & Photosystem I subunit E-2 & 46 & 33 & 14782 & 2064.2 & 1859.0 \\
\hline$N b G R F 5$ & NBOR9061 & AT5G16050 & GRF5 & 22 & 39 & 29526 & 56 & 80 \\
\hline $\mathrm{NbPI2}$ & NBOR2273 & ABX76298 & $\begin{array}{l}\text { Kunitz family trypsin and protease inhibitor } \\
\text { protein }\end{array}$ & 64 & 181 & 26843 & 394 & 2975 \\
\hline NbRBCS1A.1 & NBOR92 & AT1G67090 & Rubisco small subunit $1 \mathrm{~A}$ & 52 & 30 & 15623 & 14465 & 12930 \\
\hline$N b R B C S 1 A .2$ & NBOR58 & & & 65 & N/A & 9774 & 5855 & 2414 \\
\hline NbPSAF.1 & NBOR390 & AT1G31330 & Photosystem I subunit F & 25 & N/A & 9719 & 1477 & 651 \\
\hline$N b P S A F .2$ & NBOR392 & & & N/A & 39 & 2655 & & \\
\hline NbPSAD1 & NBOR676 & AT4G02770 & Photosystem I subunit D-1 & 23 & 44 & 22471 & 1971 & 1683 \\
\hline
\end{tabular}

a The transcriptome contig of the Nicotiana benthamiana sequence indentification number.

b The Arabidopsis Genome Initiative and European Molecular Biology Laboratory reference identification numbers.

c The liquid chromatography-tandem mass spectrometry score.

$\mathrm{d}$ The mass of the identified peptide

e Fragments per kilobase of transcript per million mapped reads (FPKM) of transcriptome from the healthy plants (mock) and from Odontoglossum ringspot virus (ORSV)-infected plants.

Table 3. Odontoglossum ringspot virus wild-type interacting capsid proteins (ORSV-CPWT) that were identified by MASCOT, using the ContigViews Nicotiana benthamiana database

\begin{tabular}{|c|c|c|c|c|c|c|c|c|}
\hline \multirow[b]{2}{*}{ Gene } & \multirow[b]{2}{*}{ Contigs ID ${ }^{a}$} & \multirow[b]{2}{*}{ Ref ID ${ }^{b}$} & \multirow[b]{2}{*}{ Description } & \multicolumn{2}{|c|}{ Score $^{c}$} & \multirow[b]{2}{*}{$\operatorname{Mass}(D a)^{d}$} & \multicolumn{2}{|c|}{ FPKM $^{\mathrm{e}}$} \\
\hline & & & & WT & $\overline{E^{100} A}$ & & Mock & $\overline{\text { ORSV }}$ \\
\hline NbFIB4 & NBOR6354 & AT3G23400 & FIBRILLIN 4 & 35 & N/A & 14845 & 211.7 & 291.5 \\
\hline$N b G O X 1$ & NBOR1162 & AT3G14420 & Glycolate oxidase 1 & 35 & N/A & 21998 & 113 & 83 \\
\hline NbSHM1.1 & NBOR327 & AT4G37930 & Serine transhydroxymethyltransferase 1 & 31 & N/A & 19214 & 633 & 245 \\
\hline$N b C N G C 1$ & NBOR12131 & AT5G53130 & Cyclic nucleotide gated channel 1 & 21 & N/A & 75186 & 15 & 42 \\
\hline$N b P I P 1 ; 4$ & NBOR145 & AT4G00430 & Plasma membrane intrinsic protein $1 ; 4$ & 22 & N/A & 12145 & 83 & 57 \\
\hline$N b F L N 1$ & NBOR16452 & AT3G54090 & FRUCTOKINASE-LIKE 1 & 30 & N/A & 55196 & 26 & 43 \\
\hline NbIIL1 & NBOR 18678 & AT4G13430 & Isopropyl malate isomerase large subunit 1 & 21 & N/A & 19023 & 46 & 123 \\
\hline NbIBS1 & NBOR22975 & AT1G18670 & Impaired in baba-induced sterility 1 & 42 & N/A & 77365 & 7 & 12 \\
\hline$N b A G T 1$ & NBOR316 & AT2G13360 & Alanine:glyoxylate aminotransferase & 40 & N/A & 22684 & 1325 & 471 \\
\hline $\mathrm{NbORC} 2$ & NBOR45173 & AT2G37560 & $\begin{array}{l}\text { Origin recognition complex second largest } \\
\text { subunit } 2\end{array}$ & 20 & N/A & 9810 & 9 & 18 \\
\hline$N b R C A$ & NBOR457 & AT2G39730 & Rubisco activase & 26 & N/A & 15745 & 13481 & 4900 \\
\hline $\mathrm{NbVCL1}$ & NBOR48019 & AT2G38020 & Vacuoleless 1 & 25 & N/A & 8655 & 4 & 2 \\
\hline$N b S K 21$ & NBOR4906 & AT3G61415 & SKP1-like 21 & 26 & N/A & 40372 & 24 & 21 \\
\hline$N b N P C 2$ & NBOR6197 & AT2G26870 & Nonspecific phospholipase C2 & 33 & N/A & 11207 & 4 & 9 \\
\hline $\mathrm{NA}^{\mathrm{f}}$ & NBOR6246 & AT3G24880 & $\begin{array}{l}\text { Helicase/SANT-associated DNA binding } \\
\text { protein }\end{array}$ & 31 & N/A & 102850 & 4 & 4 \\
\hline
\end{tabular}

a Sequence identification number from the transcriptome contig of $N$. benthamiana.

b The Arabidopsis Genome Initiative reference identification number.

c The liquid chromatography-tandem mass spectrometry score.

d The mass of the identified peptide

e Fragments per kilobase of transcript per million mapped reads (FPKM) of transcriptome from the healthy plants (mock) and from Odontoglossum ringspot virus (ORSV)-infected plants.

${ }^{\mathrm{f}}$ Not available from its common name in The Arabidopsis Information Resource database. 
The integrated omics approach and experimental validation for improving protein identification.

Traditional proteomics analysis uses the National Center for Biotechnology Information nonredundat (NCBI nr) database for protein identification. Currently, the high-throughput NGS technique provides an advantage for sequencing whole transcriptomes of nonmodel organisms, using a de novo assembly approach to bypass the requirement for genomic information (Liu et al. 2014). Through appropriate gene annotation, the integrated omics approach uses ORF information to provide a precise spectrum for protein identification. This organismspecific spectrum increases the accuracy of protein identification. Both the identification and expression of these IP can be evaluated using transcriptome assays. Therefore, the integrated omics approach provides a comprehensive view of systems biology to understand the virus-host interaction.

High-throughput data must be validated by experimental approaches to confirm the effectiveness of the high-throughput strategy. Liu et al. (2014) used customized microarrays to verify transcript expressions in a nonmodel organism. To assess proteomes, gene cloning and soluble recombinant protein purification are limiting factors in the validation of protein-protein interactions. In this study, we used the pEXP5-CT/TOPO TA technology with the Expressway Cell-Free E. coli expression system to perform quickly cloning and recombinant protein expression in vitro. The candidate genes in the expression plasmid can be used to directly express the recombinant proteins by in vitro transcription and translation. The soluble
A

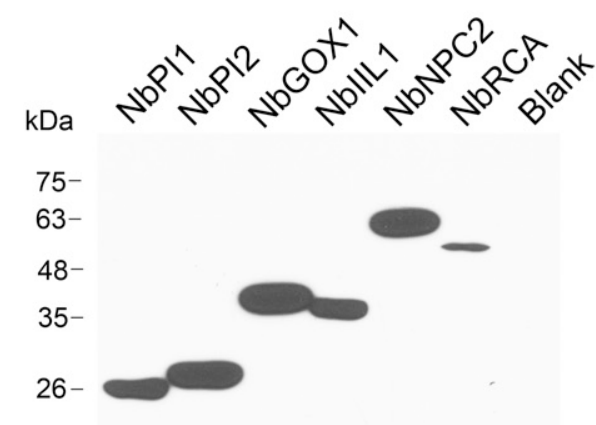

C

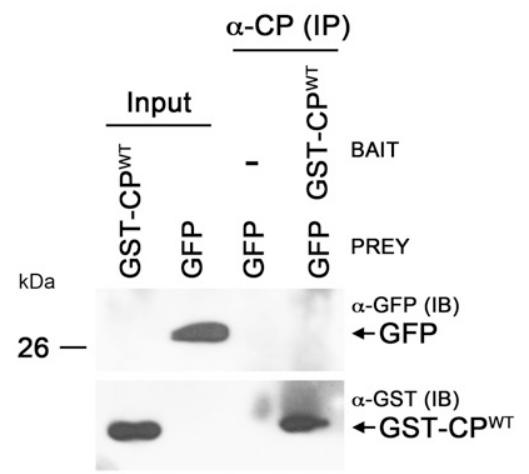

B
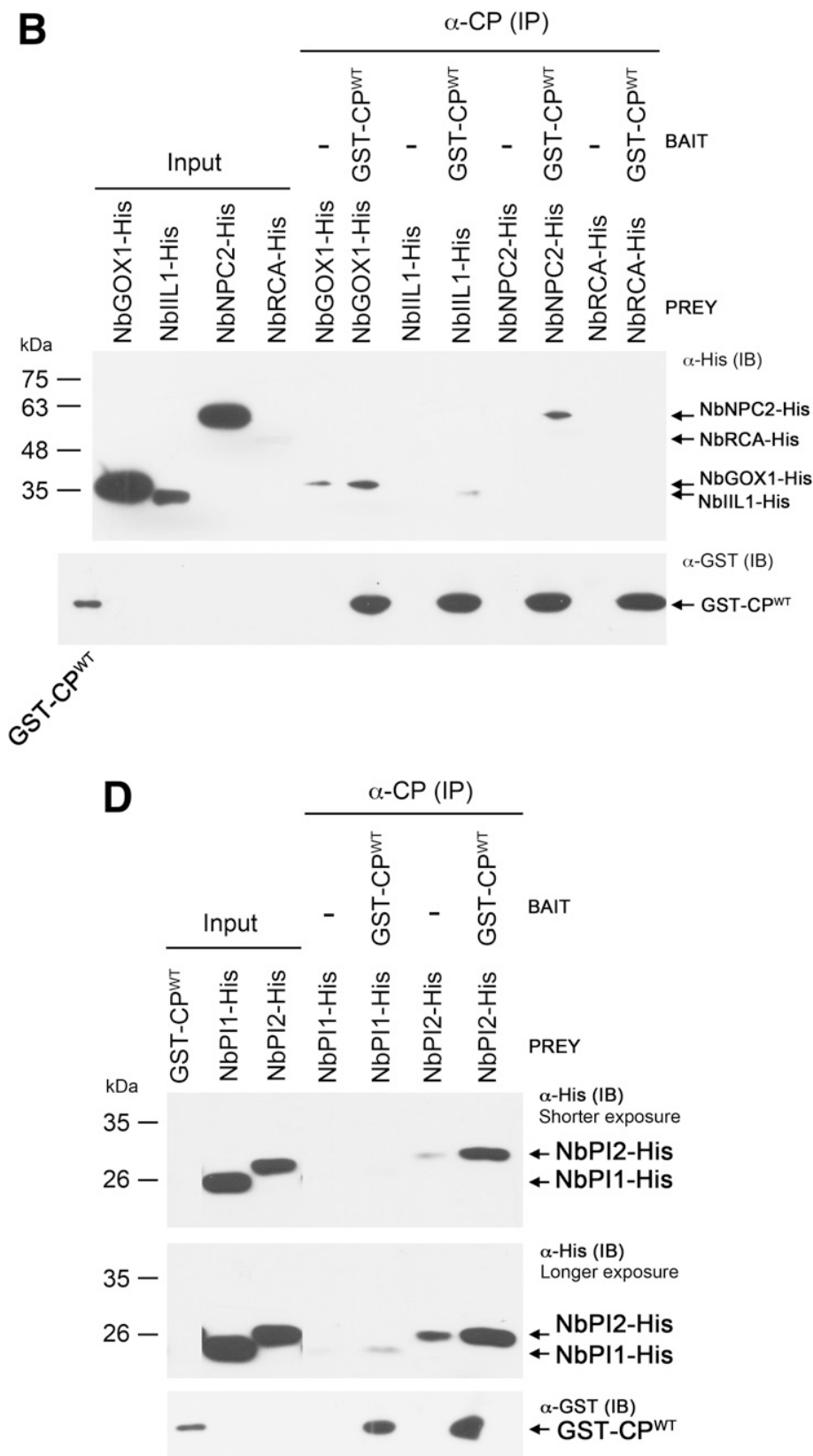

Fig. 9. Experimental validation of the physical interaction between Odontoglossum ringspot virus (ORSV) capsid protein (CP) and CP-interacting proteins CP-IP. A, In vitro transcribed or translated $\mathrm{CP}^{\mathrm{WT}}$-IP that fused with the His-tag were examined by Western blot analysis with an anti-His antibody. B, Evaluation of the protein-protein interaction between glutathione $S$-transferase (GST)-CP ${ }^{\mathrm{WT}}$ and $\mathrm{CP}^{\mathrm{WT}}$-IP by coimmunoprecipitation. The GST-CP $^{\mathrm{WT}}$ was used as bait protein, whereas His-tag fused recombinant CP ${ }^{\mathrm{WT}}$-IP were used as prey. C, The coimmunoprecipitation of GST-CP ${ }^{\mathrm{WT}}+\mathrm{GFP}^{-}$ was used as a negative control. D, Evaluation of the protein-protein interaction between GST-CP ${ }^{\mathrm{WT}}$ and NbPI1 and NbPI2 by coimmunoprecipitation. 
recombinant proteins can be used as a prey for in vitro binding assay to validate high-throughput proteomic data. Moreover, VIGS provides an advantage by quickly knocking down the gene expression for loss-of-function assays. Thus, combining omics and experimental approaches has provided a new direction in functional genomic studies of nonmodel organisms.

\section{Photosystem components aid in virus infection.}

Many reports have indicated that several photosystem components are involved in virus infection (Li et al. 2008; Manfre et al. 2011; Pineda et al. 2010; Zhang et al. 2008). In ToMV, CP was shown to colocalize with the IP-L protein on chloroplast thylakoid membranes and caused chlorosis symptoms (Li et al. 2008; Zhang et al. 2008). In addition, chloroplast impairment increases the susceptibility of the plant to Turnip mosaic virus infection (Manfre et al. 2011). Moreover, protein related to photosynthesis pathways, such as the electron-transport chain and the Benson-Calvin cycle, have been shown to be decreased in virus-infected tissue (Pineda et al. 2010). These results indicated that viral proteins might control chloroplast function to aid virus infection. Our LC-MS/MS results are consistent with the observation that most of the CP-IP were plant photosystem subunits, e.g., NbPSAE2, NbPSAF.1, NbPSAF.2, and NbPSAD1. One of the CP ${ }^{\mathrm{WT}}$-IP, NbIIL1, was highly expressed in ORSVinfected plants. AtIIL1 (AT4G13430) is a chloroplast-localized protein, and the expression levels of AtIIL1 affect leaf development (Sureshkumar et al. 2009; Zybailov et al. 2008). AtRCA (AT2G39730) is ancillary to $\mathrm{CO}_{2}$ fixation by Rubisco in photosynthesis (Boex-Fontvieille et al. 2014; Portis 2003), whereas the $\mathrm{CP}^{\mathrm{WT}}$-interacting $N b R C A$ was down-regulated in ORSV-infected plants. We suggest that $\mathrm{CP}$ targets and interacts

A

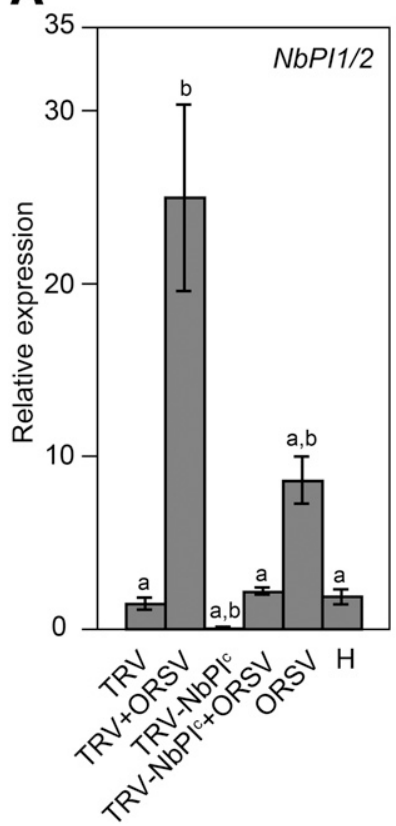

B

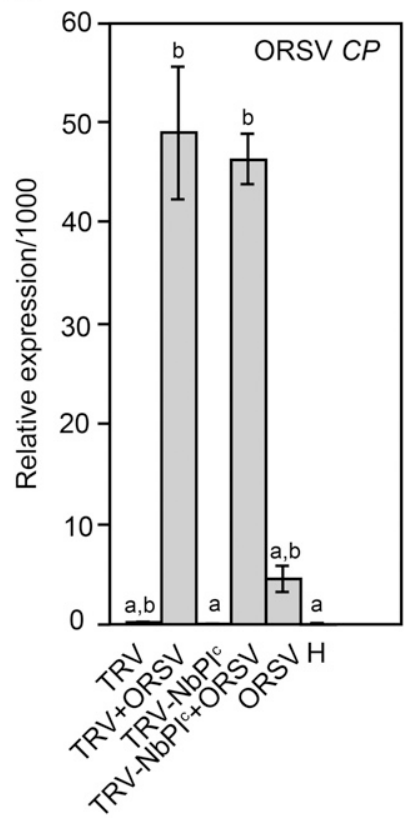

Fig. 10. Evaluation the Odontoglossum ringspot virus (ORSV) infectivity on $\mathrm{NbPI1/2}$ VIGS plants. A, The relative expression levels of $\mathrm{NbPI1}$ and NbPI2 and B, ORSV CP on plants inoculated by various Tobacco rattle virus (TRV) constructs and then challenged by ORSV were detected by real-time reverse transcription-polymerase chain reaction. The bars represent standard errors $(n=14)$. Relative expression levels were normalized with the NbEF $1 \alpha$ level. "H" indicates the healthy plants. Relative expression levels were significantly different $(P$ values $<0.01)$ from those of TRV+ORSV or H plants in each RNA sample, based on a Student's $t$ test. The letter a indicates differentially expressed (DE) to TRV+ORSV and $\mathrm{b}$ indicates $\mathrm{DE}$ to $\mathrm{H}$ plants. with chloroplast proteins to control chloroplast function during virus infection, replication, or movement.

\section{$C P^{W T}$-specific IP in response to stresses and DNA replication.}

The putative role of the nonspecific phospholipases $\mathrm{C}$ of Arabidopsis in signal transduction of the plant defense system may be attributable to diacylglycerols that generate reactive oxygen species (ROS) (Pokotylo et al. 2013; Scherer et al. 2002; Yamaguchi et al. 2005). Furthermore, AtGOX1 and AtSHM1.1 also control ROS production in Arabidopsis (Chern et al. 2013; Fahnenstich et al. 2008; Zhou et al. 2012). In addition, the plasma membrane intrinsic protein of Arabidopsis (AtPIP) is a type of aquaporin that controls transmembrane water flow to overcome chilling tolerance (Lee et al. 2012). The AtPIP1;4 aquaporin was up-regulated in roots exposed to low air temperatures (Jang et al. 2004). In the transcriptome data, NbGOX1, NbSHM1.1, and NbPIP1;4 were down-regulated following ORSV infection, whereas $N b N P C 2$ was up-regulated in ORSV-infected plants, suggesting that the two forces from virus and host counteract each other.

Moreover, the expression levels of $N b F L N 1$ and $N b O R C 2$ were induced by ORSV infection, and both proteins interact with ORSV CP ${ }^{\mathrm{WT}}$ (Supplementary Fig. 2). The Arabidopsis ortholog of AtFLN1 is involved in the function of the plastidencoded RNA polymerase in the transcriptionally active chromosomes of chloroplasts (Gilkerson et al. 2012). Furthermore, the Arabidopsis origin recognition complex (ORC) is composed of six subunits that form a prereplication complex (pre-RC) in endoreplicating cells (Diaz-Trivino et al. 2005). The pre-RC facilitates the formation of DNA replication complexes, resulting in DNA polymerase and other accessory factors to provide access to the activated origins of replicating DNA (Bell and Dutta 2002). Therefore, we hypothesize that ORSV CP ${ }^{\mathrm{WT}}$ might interfere with gene expression in chloroplasts and disrupt cell division. Because these genes are components of the nuclear complex, we cannot exclude the possibility that ORSV might recruit these components for viral replication.

NbPI1 and NbPI2 might play a role in plant immunity.

The Kunitz type of proteinase inhibitor gene of $N$. glutinosa $(N g P I)$ has been shown to be highly induced in a TMV-infected susceptible variety (SR1) and a resistant variety (N. tabacum cv. Xanthi nc) (Park et al. 2000). The rapid and transient accumulation of $N g P I$ within $24 \mathrm{~h}$ of TMV infection implies that $\mathrm{NgPI}$ is involved in a signaling process that leads to defense responses (Park et al. 2000). The ortholog of $\mathrm{NgPI}$ in Arabidopsis, AtPI (AT1G17860), was shown to be up-regulated in response to stress and geminivirus infection (Ascencio-Ibáñez et al. 2008; dit Frey et al. 2010). In N. benthamiana, two homologous genes, NbPI1 and NbPI2, were highly induced in ORSVinfected plants, but only NbPI2 had high binding affinity with ORSV CP. Furthermore, our mass spectrometry data indicated that $\mathrm{CP}^{\mathrm{E} 100 \mathrm{~A}}$ has a stronger interaction with $\mathrm{NbPI} 2$ than $\mathrm{CP}^{\mathrm{WT}}$ $\mathrm{NbPI}$. NbPI2 did not evolve a strong interaction with $\mathrm{CP}^{\mathrm{E} 100 \mathrm{~A}}$ via natural selection because the $\mathrm{CP}$ is a laboratory-created mutant. Our explanation for this phenomenon is that the substitution $\left(\mathrm{E}^{100} \mathrm{~A}\right)$ on $\mathrm{CP}$ resulted in a strong interaction with NbPI2 and that the NbPI2-CP interaction prevents viral particle assembly or prevents the systemic movement of the virus. However, the synergistic effect of coinfection resulted in an absence of differences in ORSV amounts between TRV and TRV-NbPI ${ }^{\mathrm{c}}$ VIGS plants. Stable $\mathrm{NbPI}$ RNAi transgenic plants might provide better evidence to determine whether both NbPI are important in host defense or in ORSV infection.

In conclusion, we demonstrated that viral particle assembly is associated with ORSV systemic movement in $N$. benthamiana. 
Several CP-IP were identified using an integrated omics and experimental approach, which suggested several new research directions to further elucidate the systemic movement of ORSV and its interactions with the host plant. Finally, whether NbPI1 and NbPI 2 play important roles in plant immunity requires further investigation.

\section{MATERIALS AND METHODS}

\section{Tobamovirus $\mathrm{CP}$ sequence analysis and protein} structure prediction.

The CP sequences of ORSV and other tobamoviruses were obtained from GenBank. The sequence comparison was performed using the Align X program of the Vector NTI Suit 10.0 (Invitrogen). The amino acid sequence of ORSV CP was investigated using the Protein Structure Prediction Server (Chen et al. 2006) for protein structure prediction. The results of the prediction were further refined using PyMOL.

\section{Construction of infectious clones and protein expression clones.}

To construct the single amino acid mutation $\mathrm{E}^{100} \mathrm{~A}$ of ORSV CP, pET29a(+)-ORCP (Lee and Chang 2008) containing the ORSV $C P^{W T}$ gene was mutated by PCR-mediated site-directed mutagenesis with the following set of primers, mORCPF (5'GAATAATCGAGGTGGCCAATCCGCAGAAT-3') and mORCPR (5'-ATTCTGCGGATTGGCCACCTCGATTATTC-3') (bold indicates the point mutation site; underlining indicates the $M s c \mathrm{I}$ restriction enzyme site). The amplicon was used to replace the $C P$ gene of the full-length infectious clone pORSV ${ }^{\mathrm{WT}}$ (Lee 2008) to generate pORSV ${ }^{\mathrm{E} 100 \mathrm{~A}}$.

For protein expression, the $6 \times$ His-tagged $C P^{E 100 A}$ gene was cloned into pET29a $(+)$ (Novagen) to generate pET29-CP $\mathrm{CP}^{\mathrm{E} 100 \mathrm{~A}}$. The GST-tagged $C P^{W T}$ and $C P^{E 100 A}$ genes were cloned into pGEX-4T-1 (GE Healthcare) to generate pGEX-CP ${ }^{\mathrm{WT}}$ and pGEX-CP ${ }^{\mathrm{E} 100 \mathrm{~A}}$, respectively.

\section{Plant materials and virus inoculation.}

ORSV in vitro infectious clones harboring a wild-type genome $\left(\mathrm{pORSV}^{\mathrm{WT}}\right)$ or a mutant CP gene (pORSV ${ }^{\mathrm{E} 100 \mathrm{~A}}$ ) were expressed from a T7 promoter. For plant inoculation, capped RNA transcripts were generated by T7 RNA polymerase (New England BioLabs) and were inoculated on fully expanded leaves of $N$. benthamiana or $C$. quinoa ( 0.3 to $0.5 \mu \mathrm{g}$ of transcript RNAs per leaf). The inoculated plants were housed in the greenhouse with a 16-h light period.

\section{RNA extraction, RT-PCR, and RNA deep-sequencing analysis.}

The plant total RNA extraction miniprep system (Viogene) was used for the preparation of plant total RNA. The ORCP-F1 and ORCP-R1 primers were used for RT-PCR analysis of the ORSV CP gene (Lee and Chang 2006). MscI digestion (New England BioLabs) was performed to discriminate ORSV ${ }^{\mathrm{E} 100 \mathrm{~A}}$ from ORSV ${ }^{\mathrm{WT}}$. The PCR products and the digested products were analyzed by $1.5 \%$ agarose gel electrophoresis. For RNA deep sequencing, total RNA was prepared from healthy or 10-dpi ORSV ${ }^{\mathrm{WT}}$-infected $N$. benthamiana plants, according to the manufacturer's instructions. Deep sequencing was performed using an Illumina Hiseq 2000 instrument (Genomics BioSci \& Tech Co.). The transcriptomes were obtained using the de novo assembler in CLC Genomics Workbench 5.1 (CLC bio). The transcriptome expression profiles and database are available on the ContigViews web server. Name-calling and ORF annotations were determined using the rule-based predictor of ContigViews. The FPKM were calculated using Bowtie2 and eXpress-D software (Langmead and Salzberg 2012; Roberts et al. 2013). Differential expression analysis between healthy and $\mathrm{ORSV}^{\mathrm{WT}}$-infected plants was performed with BioConductor (Gentleman et al. 2004) and the DESeq2 package (Love et al. 2014). Gene set enrichment analysis for annotated contigs with at least twofold change of expressions between healthy and $\mathrm{ORSV}^{\mathrm{WT}}$-infected plants was accomplished by agriGO toolkit (Du et al. 2010).

\section{Western blot analysis.}

Protein samples were extracted with $10 \mathrm{mM}$ sodium phosphate buffer ( $\mathrm{pH} 7.2$ ), were separated in a $12.5 \%$ sodium dodecyl sulfate (SDS) -polyacrylamide gel electrophoresis mini-gel and transferred to polyvinylidene diflouride membranes (GE Healthcare). Western blot analysis was conducted with rabbit anti-ORSV CP antiserum (Lee and Chang 2008), an anti-His polyclonal antibody (LTK BioLaboratories), or an anti-GST polyclonal antibody (LTK BioLaboratories). Gels or membranes were stained with Coomassie brilliant blue R250, and the expression level of Rubisco was used as a loading control.

\section{ISEM.}

A carbon-coated Formvar copper grid (200 mesh) was incubated with an anti-ORSV CP antibody solution that was diluted in $10 \mathrm{mM}$ sodium phosphate buffer ( $\mathrm{pH}$ 7.2) for $15 \mathrm{~min}$ at room temperature. The antibody-coated grid was incubated with a virion solution derived from leaf extracts prepared in 10 volumes of (vol/wt) $10 \mathrm{mM}$ sodium phosphate buffer $(\mathrm{pH} 7.2)$ and were centrifuged at 10,000 rpm (Eppendorf Centrifuge 5424) for $3 \mathrm{~min}$ to discard the cell debris. The grid was further incubated with an anti-ORSV CP antibody for $15 \mathrm{~min}$ at room temperature. Excess liquid was carefully removed from the edge of the grid, using a deckle-edged paper. Two percent phosphotungstic acid ( $\mathrm{pH}$ 7.0) was dripped onto the semidry grid, and the sample was negative stained for $1 \mathrm{~min}$. The liquid was removed using deckle-edged paper, and the grid was allowed to air dry for at least 2 days before observation through a transmission electron microscope. Photographs were taken at a magnification of 80,000 , and the size of the viral particle was calculated using the detector on the real-time images.

\section{Size-exclusion chromatography.}

Plant tissues were homogenized in 2 to 4 volumes of extraction buffer $(200 \mathrm{mM}$ Tris- $\mathrm{HCl}, \mathrm{pH} 7.4,150 \mathrm{mM} \mathrm{NaCl}, 5 \mathrm{mM}$ dithiothreitol [DTT], protease inhibitor cocktail [Roche Applied Science] and proteasome inhibitor set II [Calbiochem]) and were centrifuged twice at 10,000 rpm (Eppendorf Centrifuge 5424) for $10 \mathrm{~min}$ at $4^{\circ} \mathrm{C}$ to remove the cell debris. The plant extracts were loaded onto a HiPrep 16/60 Sephacryl S-200 HR column (GE Healthcare), using the AKTA Explorer Fast protein liquid chromatography (FPLC) system. The FPLC system was run at a constant flow rate at $0.5 \mathrm{ml} / \mathrm{min}$ and fractions were collected every $2 \mathrm{ml}$. A $10-\mu \mathrm{l}$ aliquot of each fraction was analyzed by Western blot analysis with anti-ORSV CP antiserum. The excess unloading plant extract was saved as input control, and additional FPLC runs with given size markers were conducted to mark the relative sizes of the FPLC fractions.

\section{In vitro CP-CP interaction assay.}

Protein coprecipitation was performed by incubating GST, GST-CP ${ }^{\mathrm{WT}}$, or GST-CP ${ }^{\mathrm{E} 100 \mathrm{~A}}$ with $\mathrm{CP}^{\mathrm{WT}}$-His or $\mathrm{CP}^{\mathrm{E} 100 \mathrm{~A}}$-His in coprecipitation buffer $(50 \mathrm{mM}$ Tris, $\mathrm{pH} 7.5,100 \mathrm{mM} \mathrm{NaCl}$, $1 \mathrm{mM}$ EDTA, $3 \mathrm{mM}$ DTT plus $0.25,0.5$, or $1 \%$ Triton X-100) at $4^{\circ} \mathrm{C}$ for $1 \mathrm{~h}$. PureProteome nickel magnetic beads (Millipore) were added at $4^{\circ} \mathrm{C}$ for $1 \mathrm{~h}$ to capture the target proteins. A magnetic stand for a $0.2-\mathrm{ml}$ tube (DYNAL MPC-9600; Invitrogen) was used to pull down the magnetic protein complex. After five washes with coprecipitation buffer, the pulled-down 
product was resuspended in $2 \times$ sample buffer $(2 \%$ SDS, $10 \%$ glycerol, $1 \% \beta$-mercaptoethanol, $0.005 \%$ bromophenol blue, $50 \mathrm{mM}$ Tris- $\mathrm{HCl}, \mathrm{pH} 6.8$ ), was boiled at $96^{\circ} \mathrm{C}$ for $10 \mathrm{~min}$, and was loaded onto a $12 \%$ SDS polyacrylamide gel. Western blot analysis was performed with an anti-GST polyclonal antibody to detect the existence of the GST fusion protein.

\section{Coimmunoprecipitation and LC-MS/MS identification.}

The Pierce crosslink immunoprecipitation kit (Thermo Scientific) was used to pull down the protein complex with affinity-purified anti-ORSV CP immunoglobulin G. After SDSpolyacrylamide gel electrophoresis, silver staining was performed. In brief, the gel was fixed overnight in fixing solution ( $50 \%$ methanol, $10 \%$ acetic acid, $0.05 \%$ formalin), was washed twice in $35 \%$ ethanol for 20 min for each wash, was sensitized in $0.02 \% \mathrm{Na}_{2} \mathrm{~S}_{2} \mathrm{O}_{3}$ for $2 \mathrm{~min}$, and finally, was washed in doubledistilled (dd) $\mathrm{H}_{2} \mathrm{O}$ three times for $5 \mathrm{~min}$ each. The gel was stained with staining solution $\left(0.2 \% \mathrm{AgNO}_{3}\right.$ and $0.076 \%$ formalin) for $30 \mathrm{~min}$ and was washed in $\mathrm{ddH}_{2} \mathrm{O}$ for $1 \mathrm{~min}$. Finally, the silver color was developed in developing solution $(6 \%$ $\mathrm{Na}_{2} \mathrm{CO}_{3}, 0.05 \%$ formalin, and $0.0004 \% \mathrm{Na}_{2} \mathrm{~S}_{2} \mathrm{O}_{3}$ ) for approximately $1 \mathrm{~min}$. All incubations were performed at room temperature.

Coomassie blue staining was used instead of silver staining to decrease the incompatibility of the LC-MS/MS analysis. The gel pieces were destained with $25 \mathrm{mM}$ ammonium bicarbonate (ABC) and 50\% acetonitrile, were reduced with $10 \mathrm{mM}$ DTT and $25 \mathrm{mM} \mathrm{ABC}$ at $56^{\circ} \mathrm{C}$ for $1 \mathrm{~h}$, and were alkylated with $55 \mathrm{mM}$ iodoacetamide and $25 \mathrm{mM} \mathrm{ABC}$ at room temperature for $45 \mathrm{~min}$. Trypsin (Promega) was used to digest the proteins into peptides at $37^{\circ} \mathrm{C}$ for $16 \mathrm{~h}$ (trypsin/total proteins $=1: 50$ ). The extracted peptides were desalted using C18 ZipTIP (Millipore) prior to LC-MS/MS analysis. The LC-MC/MC analyses were performed using a quadrupole time-of-flight mass spectrometer (Synapt G1; Waters) coupled with a nano ultrahigh performance liquid chromatography (nanoUHPLC) system (nanoACQUITY; Waters) and a tunnel frit nanoUHPLC column, as described in a previous study (Chen et al. 2012). The acquired MS/MS spectra were processed by UniQua (Chang et al. 2013), using the SynaptG1 preset parameter to obtain a fragment monoisotopic peak list, and were searched against the ContigViews $N$. benthamiana transcriptome database and NCBI nr protein database, using the MASCOT algorithm (Matrix Science) with previously described search parameters (Chen et al. 2010).

The proteins that were identified in the healthy sample were subtracted from the list of $\mathrm{CP}^{\mathrm{WT}}$ - and $\mathrm{CP}^{\mathrm{E} 100 \mathrm{~A}}-\mathrm{IP}$. The detailed identification scores of the $\mathrm{CP}^{\mathrm{WT}}$ and $\mathrm{CP}^{\mathrm{E} 100 \mathrm{~A}}$-IP are listed in Supplementary Table 3.

\section{In vitro transcription and translation for rapid validation of protein interaction.}

The $C P^{W T}-I P$ genes were amplified by RT-PCR with $T a q$ DNA polymerase (Ampliqon) to obtain an extra "A" at the 3 ' ends for TA cloning. The primers used for RT-PCR are listed in Supplementary Table 4. The pEXP5-CT/TOPO TA expression kit (Invitrogen) was used for cloning $C P^{W T}-I P$ genes, which were fused with a $6 \times \mathrm{His}$-Tag at the $\mathrm{C}$-terminus of the recombinant protein. One microgram of the plasmid was used for in vitro cell-free transcription or translation for the recombinant protein production by Expressway Cell-Free E. coli expression system (Invitrogen). Each $5 \mu$ of lysate containing CP-IP recombinant protein was incubated with $2 \mu \mathrm{g}$ of GST-CP ${ }^{\mathrm{WT}}$ recombinant protein in coprecipitation buffer $(50 \mathrm{mM}$ Tris, $\mathrm{pH} 7.5,100 \mathrm{mM}$ $\mathrm{NaCl}, 0.2 \%$ glycerol, $0.6 \%$ Triton $\mathrm{X}-100$, and $0.5 \mathrm{mM}$ $\beta$-mercaptoethanol) at room temperature for $1 \mathrm{~h}$ and was then applied with $10 \mu \mathrm{g}$ of anti-ORSV CP polyclonal immunoglobulins and $30 \mu \mathrm{l}$ of balanced suspension of Protein G PLUS-agarose beads
(Santa Cruz Biotechnology) for protein-capturing at room temperature for another $1 \mathrm{~h}$. The protein-captured beads were washed twice with wash buffer $(50 \mathrm{mM}$ Tris, $\mathrm{pH} 7.5,100 \mathrm{mM}$ $\mathrm{NaCl}, 0.6 \%$ Triton $\mathrm{X}-100)$. Final precipitant was suspended in $20 \mu \mathrm{l}$ of $2 \times$ sample buffer ( $2 \%$ SDS, $10 \%$ glycerol, $1 \%$ $\beta$-mercaptoethanol, $0.005 \%$ bromophenol blue, $50 \mathrm{mM}$ Tris- $\mathrm{HCl}$, $\mathrm{pH}$ 6.8) and was analyzed by Western blot for prey detection with anti-His (C-term)-horseradish peroxidase antibody (Invitrogen) or anti-GFP monoclonal antibody (GeneTex). The captured bait was measured by anti-GST monoclonal antibody (Bioman Scientific).

\section{VIGS for $\mathrm{NbPII}$ and $\mathrm{NbPI2}$.}

The 485-bp coding region (30 to $514 \mathrm{bp}$ ) of $N b P I 2$ was amplified with NbPIVIGSF1 and NbPIVIGSR1 primers by RTPCR because the region is highly conserved with $N b P I 1$. The RT-PCR product was cloned into pCR8/GW/TOPO vector (Invitrogen) to generate pCR8-TOPO-NBPI. The 485-bp fragment of $\mathrm{NbPI} 2\left(\mathrm{NbPI}^{\mathrm{c}}\right)$ was transferred into the TRV2-pYL279 plasmid (Liu et al. 2002) by a Gateway recombination system (Invitrogen) to generate pTRV2-NbPI ${ }^{\mathrm{c}}$. Agrobacterium tumefaciens (strain GV3101) was used to express pTRV1 (TRV RNA1) and pTRV2-NbPI following agroinfiltration to generate the TRV$\mathrm{NbPI}^{\mathrm{c}}$ virus in $N$. benthamiana plants for virus inoculum. TRV was used as a negative control.

For VIGS of $N b P I 1$ and NbPI2, the 3-week-old N. benthamiana plant was used and the first to fifth leaves (counted from the base) were used for TRV-NbPI ${ }^{\mathrm{c}}$ inoculation. After $7 \mathrm{dpi}, \mathrm{NbPII/2-VIGS}$ plants were challenged with ORSV on the seventh and eighth leaves by mechanical inoculation. After 7 days of ORSV challenging inoculation, the twelfth and thirteenth leaves were collected for RNA extraction with the plant total RNA isolation kit (Viogene). Reverse transcription was performed using the SuperScript III first-strand synthesis system (Invitrogen) with oligo-dT and ORSV $C P$-specific reverse primers. $N b P I I$ and NbPI2 expression were evaluated for VIGS efficiency by detecting the conserved region with real-time RT-PCR, using a LightCycler 480 instrument (Roche). In addition, the ORSV $C P$ RNA amounts were evaluated by real-time RT-PCR. The $N b E F 1 \alpha$ level was used as internal control. The NbPI, ORSV $C P$, and $N b E F 1 \alpha$ transcripts were quantified via a relative cycle threshold $(\mathrm{Ct})$ method. All of the experiments were performed with three independent replicates to compensate possible loading errors. The relative expression levels were calculated based on the $\Delta \Delta \mathrm{Ct}$ value, and each sample was normalized according to the expression level of $N b E F 1 \alpha$.

\section{ACKNOWLEDGMENTS}

This work was supported by grants from the Ministry of Science and Technology, Taiwan (NSC-102-2313-B-002-068-MY3 and NSC-102-2313B-002-066-B-MY3) to S.-S. Lin. and (NSC99-2313-B-002-043-MY3) to Y.-C. Chang. S.-S. Lin and Y.-C. Chang designed the research methods. P.-C. Lin, W.-C. Hu, S.-C. Lee, and P.-Y. Chen performed the experiments. Y.-R. Chen designed the proteomics workflow. Y.-L. Chen, and C.-Y. Lee performed the proteomics analysis and data analysis. L.-Y. Liu performed the statistical assays on the deep sequence data. All of the authors discussed the results and commented on the manuscript, which was written by P.-C. Lin, Y.-C. Chang, and S.-S. Lin.

\section{LITERATURE CITED}

Adams, M. J., Antoniw, J. F., and Kreuze, J. 2009. Virgaviridae: A new family of rod-shaped plant viruses. Arch. Virol. 154:1967-1972.

Ascencio-Ibáñez, J. T., Sozzani, R., Lee, T. J., Chu, T. M., Wolfinger, R. D. Cella, R., and Hanley-Bowdoin, L. 2008. Global analysis of Arabidopsis gene expression uncovers a complex array of changes impacting pathogen response and cell cycle during geminivirus infection. Plant Physiol. 148: 436-454. 
Bell, S. P., and Dutta, A. 2002. DNA replication in eukaryotic cells. Annu. Rev. Biochem. 71:333-374.

Bendahmane, M., Fitchen, J. H., Zhang, G., and Beachy, R. N. 1997. Studies of coat protein-mediated resistance to Tobacco mosaic tobamovirus: Correlation between assembly of mutant coat proteins and resistance. J. Virol. 71:7942-7950.

Boex-Fontvieille, E., Daventure, M., Jossier, M., Hodges, M., Zivy, M., and Tcherkez, G. 2014. Phosphorylation pattern of Rubisco activase in Arabidopsis leaves. Plant Biol Stuttg 16:550-557.

Chang, W. H., Lee, C. Y., Lin, C. Y., Chen, W. Y., Chen, M. C., Tzou, W. S., and Chen, Y. R. 2013. UniQua: A universal signal processor for MSbased qualitative and quantitative proteomics applications. Anal. Chem. 85:890-897.

Chen, M. H., and Citovsky, V. 2003. Systemic movement of a tobamovirus requires host cell pectin methylesterase. Plant J. 35:386-392.

Chen, M. H., Sheng, J., Hind, G., Handa, A. K., and Citovsky, V. 2000. Interaction between the Tobacco mosaic virus movement protein and host cell pectin methylesterases is required for viral cell-to-cell movement. EMBO (Eur. Mol. Biol. Organ.) J. 19:913-920.

Chen, C. C., Hwang, J. K., and Yang, J. M. 2006. (PS)2: Protein structure prediction server. Nucleic Acids Res. 34:W152-W157.

Chen, C. J., Tseng, M. C., Lin, H. J., Lin, T. W., and Chen, Y. R. 2010. Visual indicator for surfactant abundance in MS-based membrane and general proteomics applications. Anal. Chem. 82:8283-8290.

Chen, C. J., Chen, W. Y., Tseng, M. C., and Chen, Y. R. 2012. Tunnel frit: A nonmetallic in-capillary frit for nanoflow ultra high-performance liquid chromatography-mass spectrometryapplications. Anal. Chem. 84:297-303.

Chern, M., Bai, W., Chen, X., Canlas, P. E., and Ronald, P. C. 2013. Reduced expression of glycolate oxidase leads to enhanced disease resistance in rice. PeerJ 1:e28.

Dawson, W. O., Bubrick, P., and Grantham, G. L. 1988. Modifications of the Tobacco mosaic virus coat protein gene affecting replication, movement, and symptomatology. Phytopathgology 78:783-789.

Diaz-Trivino, S., del Mar Castellano, M., de la Paz Sanchez, M., RamirezParra, E., Desvoyes, B., and Gutierrez, C. 2005. The genes encoding Arabidopsis ORC subunits are E2F targets and the two ORC1 genes are differently expressed in proliferating and endoreplicating cells. Nucleic Acids Res. 33:5404-5414.

dit Frey, N. F., Muller, P., Jammes, F., Kizis, D., Leung, J., PerrotRechenmann, C., and Bianchi, M. W. 2010. The RNA binding protein Tudor-SN is essential for stress tolerance and stabilizes levels of stressresponsive mRNAs encoding secreted proteins in Arabidopsis. Plant Cell 22:1575-1591.

Du, Z., Zhou, X., Ling, Y., Zhang, Z., and Su, Z. 2010. agriGO: A GO analysis toolkit for the agricultural community. Nucleic Acids Res. 38: W64-W70.

Fahnenstich, H., Scarpeci, T. E., Valle, E. M., Flügge, U. I., and Maurino, V. G. 2008. Generation of hydrogen peroxide in chloroplasts of Arabidopsis overexpressing glycolate oxidase as an inducible system to study oxidative stress. Plant Physiol. 148:719-729.

Gentleman, R. C., Carey, V. J., Bates, D. M., Bolstad, B., Dettling, M., Dudoit, S., Ellis, B., Gautier, L., Ge, Y., Gentry, J., Hornik, K., Hothorn, T., Huber, W., Iacus, S., Irizarry, R., Leisch, F., Li, C., Maechler, M., Rossini, A. J., Sawitzki, G., Smith, C., Smyth, G., Tierney, L., Yang, J. Y., and Zhang, J. 2004. Bioconductor: Open software development for computational biology and bioinformatics. Genome Biol. 5:R80.

Gilkerson, J., Perez-Ruiz, J. M., Chory, J., and Callis, J. 2012. The plastidlocalized pfkB-type carbohydrate kinases FRUCTOKINASE-LIKE 1 and 2 are essential for growth and development of Arabidopsis thaliana. BMC Plant Biol. 12:102.

Guarnieri, M. T., Nag, A., Smolinski, S. L., Darzins, A., Seibert, M., and Pienkos, P. T. 2011. Examination of triacylglycerol biosynthetic pathways via de novo transcriptomic and proteomic analyses in an unsequenced microalga. PLoS ONE 6:e25851.

Hicks, G. R., Rojo, E., Hong, S., Carter, D. G., and Raikhel, N. V. 2004. Geminating pollen has tubular vacuoles, displays highly dynamic vacuole biogenesis, and requires VACUOLESS1 for proper function. Plant Physiol. 134:1227-1239.

Hilf, M. E., and Dawson, W. O. 1993. The tobamovirus capsid protein functions as a host-specific determinant of long-distance movement. Virology 193:106-114.

Holt, C. A., and Beachy, R. N. 1991. In vivo complementation of infectious transcripts from mutant Tobacco mosaic virus cDNAs in transgenic plants. Virology 181:109-117.

Hong, Y., Shi, N. N., Xu, Y., Yang, K. F., Chen, Y., Wang, H. Z., and Xu, X. B. 2011. Development of a sensitive diagnostic assay to detect Cymbidium mosaic virus and Odontoglossum ringspot virus in members of the Orchidaceae. J. Hortic. Sci. Biotechnol. 86:69-73.
Howe, E. A., Sinha, R., Schlauch, D., and Quackenbush, J. 2011. RNA-Seq analysis in MeV. Bioinformatics 27:3209-3210.

Jang, J. Y., Kim, D. G., Kim, Y. O., Kim, J. S., and Kang, H. 2004. An expression analysis of a gene family encoding plasma membrane aquaporins in response to abiotic stresses in Arabidopsis thaliana. Plant Mol. Biol. 54:713-725.

Karran, R. A., and Sanfaçon, H. 2014. Tomato ringspot virus coat protein binds to ARGONAUTE 1 and suppresses the translation repression of a reporter gene. Mol. Plant Microbe Interact. 27:933-943.

Khentry, Y., Paradornuwat, A., Tantiwiwat, S., Phansiri, S., and Thaveechai, N. 2006. Incidence of Cymbidium mosaic virus and Odontoglossum ringspot virus in Dendrobium spp. in Thailand. Crop Prot. 25:926-932.

Langmead, B., and Salzberg, S. L. 2012. Fast gapped-read alignment with Bowtie 2. Nat. Methods 9:357-359.

Lee, S. C. 2008. Development of detection methods for two important orchid viruses, Cymbidium mosaic virus (CymMV) and Odontoglossum ringspot virus (ORSV), and construction and characterization of ORSV infectious cDNA clone. Ph.D. dissertation. Graduate Institute of Plant Pathology and Microbiology, National Tawan University, Taipei.

Lee, S. C., and Chang, Y. C. 2006. Multiplex RT-PCR detection of two orchid viruses with an internal control of plant nad5 mRNA. Plant Path. Bulletin 15:187-196.

Lee, S. C., and Chang, Y. C. 2008. Performances and application of antisera produced by recombinant capsid proteins of Cymbidium mosaic virus and Odontoglossum ringspot virus. Eur. J. Plant Pathol. 122:297-306.

Lee, S. H., Chung, G. C., Jang, J. Y., Ahn, S. J., and Zwiazek, J. J. 2012. Overexpression of PIP2;5 aquaporin alleviates effects of low root temperature on cell hydraulic conductivity and growth in Arabidopsis. Plant Physiol. 159:479-488.

Li, Y., Wu, M. Y., Song, H. H., Hu, X., and Qiu, B. S. 2005. Identification of a tobacco protein interacting with tomato mosaic virus coat protein and facilitating long-distance movement of virus. Arch. Virol. 150: 1993-2008.

Li, J., Brader, G., and Palva, E. T. 2008. Kunitz trypsin inhibitor: An antagonist of cell death triggered by phytopathogens and fumonisin b1 in Arabidopsis. Mol. Plant 1:482-495.

Liu, Y., Schiff, M., and Dinesh-Kumar, S. P. 2002. Virus-induced gene silencing in tomato. Plant J. 31:777-786.

Liu, L. Y., Tseng, H. I., Lin, C. P., Lin, Y. Y., Huang, Y. H., Huang, C. K., Chang, T. H., and Lin, S. S. 2014. High-throughput transcriptome analysis of the leafy flower transition of Catharanthus roseus induced by peanut witches'-broom phytoplasma infection. Plant Cell Physiol. 55: 942-957.

Love, M. I., Huber, W., and Anders, S. 2014. Moderated estimation of fold change and dispersion for RNA-Seq data with DESeq2. Genome Biol. 15:550

Manfre, A., Glenn, M., Nuñez, A., Moreau, R. A., and Dardick, C. 2011. Light quantity and photosystem function mediate host susceptibility to Turnip mosaic virus via a salicylic acid-independent mechanism. Mol. Plant Microbe Interact. 24:315-327.

Park, K. S., Cheong, J. J., Lee, S. J., Suh, M. C., and Choi, D. 2000. A novel proteinase inhibitor gene transiently induced by tobacco mosaic virus infection. Biochim. Biophys. Acta 1492:509-512.

Pineda, M., Sajnani, C., and Barón, M. 2010. Changes induced by the Pepper mild mottle tobamovirus on the chloroplast proteome of Nicotiana benthamiana. Photosynth. Res. 103:31-45.

Pokotylo, I., Pejchar, P., Potocký, M., Kocourková, D., Krčková, Z., Ruelland, E., Kravets, V., and Martinec, J. 2013. The plant non-specific phospholipase C gene family. Novel competitors in lipid signalling. Prog. Lipid Res. 52:62-79.

Portis, A. R., Jr. 2003. Rubisco activase - Rubisco's catalytic chaperone. Photosynth. Res. 75:11-27.

Rabindran, S., Robertson, C., Achor, D., German-Retana, S., A Holt, C., and Dawson, W. O. 2005. Odontoglossum ringspot virus host range restriction in Nicotiana sylvestris maps to the replicase gene. Mol. Plant Pathol. 6:439-447.

Roberts, A., Feng, H., and Pachter, L. 2013. Fragment assignment in the cloud with eXpress-D. BMC Bioinformatics 14:358.

Saito, T., Yamanaka, K., and Okada, Y. 1990. Long-distance movement and viral assembly of tobacco mosaic virus mutants. Virology 176:329-336.

Scherer, G. F., Paul, R. U., Holk, A., and Martinec, J. 2002. Downregulation by elicitors of phosphatidylcholine-hydrolyzing phospholipase $\mathrm{C}$ and up-regulation of phospholipase $\mathrm{A}$ in plant cells. Biochem. Biophys. Res. Commun. 293:766-770.

Siegel, A., Zaitlin, M., and Sehgal, O. P. 1962. The isolation of defective tobacco mosaic virus strains. Proc. Natl. Acad. Sci. USA 48:1845-1851.

Singh, D. K., Maximova, S. N., Jensen, P. J., Lehman, B. L., Ngugi, H. K., and McNellis, T. W. 2010. FIBRILLIN4 is required for plastoglobule 
development and stress resistance in apple and Arabidopsis. Plant Physiol. 154:1281-1293.

Slaughter, A., Daniel, X., Flors, V., Luna, E., Hohn, B., and Mauch-Mani, B. 2012. Descendants of primed Arabidopsis plants exhibit resistance to biotic stress. Plant Physiol. 158:835-843.

Su, C. L., Chao, Y. T., Alex Chang, Y. C., Chen, W. C., Chen, C. Y., Lee, A. Y., Hwa, K. T., and Shih, M. C. 2011. De novo assembly of expressed transcripts and global analysis of the Phalaenopsis aphrodite transcriptome. Plant Cell Physiol. 52:1501-1514.

Sureshkumar, S., Todesco, M., Schneeberger, K., Harilal, R., Balasubramanian, S., and Weigel, D. 2009. A genetic defect caused by a triplet repeat expansion in Arabidopsis thaliana. Science 323:1060-1063.

Takamatsu, N., Ishikawa, M., Meshi, T., and Okada, Y. 1987. Expression of bacterial chloramphenicol acetyltransferase gene in tobacco plants mediated by TMV-RNA. EMBO (Eur. Mol. Biol. Organ.) J. 6:307-311.

Ueki, S., and Citovsky, V. 2002. The systemic movement of a tobamovirus is inhibited by a cadmium-ion-induced glycine-rich protein. Nat. Cell Biol. 4:478-486.

Van Moerkercke, A., Fabris, M., Pollier, J., Baart, G. J., Rombauts, S., Hasnain, G., Rischer, H., Memelink, J., Oksman-Caldentey, K. M., and Goossens, A. 2013. CathaCyc, a metabolic pathway database built from Catharanthus roseus RNA-Seq data. Plant Cell Physiol. 54:673-685.

Wang, Y. F., Munemasa, S., Nishimura, N., Ren, H. M., Robert, N., Han, M., Puzõrjova, I., Kollist, H., Lee, S., Mori, I., and Schroeder, J. I. 2013. Identification of cyclic GMP-activated nonselective Ca2+-permeable cation channels and associated CNGC5 and CNGC6 genes in Arabidopsis guard cells. Plant Physiol. 163:578-590.

Wong, S. M., Chng, C. G., Lee, Y. H., Tan, K., and Zettler, F. W. 1994. Incidence of Cymbidium mosaic and Odontoglossum ringspot viruses and their significance in orchid cultivation in Singapore. Crop Prot. 13: 235-239.

Yamaguchi, T., Minami, E., Ueki, J., and Shibuya, N. 2005. Elicitorinduced activation of phospholipases plays an important role for the induction of defense responses in suspension-cultured rice cells. Plant Cell Physiol. 46:579-587.

Yu, H. H., and Wong, S. M. 1998. A DNA clone encoding the full-length infectious genome of odontoglossum ringspot tobamovirus and mutagenesis of its coat protein gene. Arch. Virol. 143:163-171.

Zhang, C., Liu, Y., Sun, X., Qian, W., Zhang, D., and Qiu, B. 2008. Characterization of a specific interaction between IP-L, a tobacco protein localized in the thylakoid membranes, and Tomato mosaic virus coat protein. Biochem. Biophys. Res. Commun. 374:253-257.

Zhang, Q., Lee, J., Pandurangan, S., Clarke, M., Pajak, A., and Marsolais, F. 2013. Characterization of Arabidopsis serine:glyoxylate aminotransferase, AGT1, as an asparagine aminotransferase. Phytochemistry 85: 30-35.

Zhao, D., Ni, W., Feng, B., Han, T., Petrasek, M. G., and Ma, H. 2003. Members of the Arabidopsis-SKP1-like gene family exhibit a variety of expression patterns and may play diverse roles in Arabidopsis. Plant Physiol. 133:203-217.

Zhou, H., Zhao, J., Yang, Y., Chen, C., Liu, Y., Jin, X., Chen, L., Li, X., Deng, X. W., Schumaker, K. S., and Guo, Y. 2012. Ubiquitin-specific protease 16 modulates salt tolerance in Arabidopsis by regulating $\mathrm{Na}^{+} / \mathrm{H}^{+}$ antiport activity and serine hydroxymethyltransferase stability. Plant Cell 24:5106-5122.

Zybailov, B., Rutschow, H., Friso, G., Rudella, A., Emanuelsson, O., Sun, Q., and van Wijk, K. J. 2008. Sorting signals, N-terminal modifications and abundance of the chloroplast proteome. PLoS ONE 3:e1994.

\section{AUTHOR-RECOMMENDED INTERNET RESOURCES}

The Protein Structure Prediction server: ps2.life.nctu.edu.tw PyMOL molecular visualization system: www.pymol.org National Taiwan University's ContigViews web server: www.contigviews.bioagri.ntu.edu.tw 